\title{
TELAAH LITERATUR TENTANG DAKWAH DI INDONESIA
}

\author{
Oleh: \\ Alamsyah \& Mery Yanti \\ Universitas Sriwijaya Palembang, Indonesia \\ alamsyah78@fisip.unsri.ac.id \\ mery.yanti@fisip.unsri.ac.id
}

\begin{abstract}
:
Da'wah is one of the important elements in all religions. In Indonesia, a lot of research on da'wah has been done by scientists, but no one has tried to map the results of knowledge that have been done by these researchers. Therefore, this article aims to get an idea of the theoretical knowledge that has been produced by da'wah researchers in Indonesia. From the results of an analysis of 44 articles that became the sample of the study, we concluded that the phenomenon of da'wah was studied in a more descriptive qualitative manner. The focus of the research is still limited to the issue of exclusive preaching messages and the practice of preaching carried out by civil society. Research on exclusive preaching messages, aspects of preaching management and organization, and preaching activities of government institutions and private corporations are rarely explored. The researcher discusses the theoretical and practical implications of these findings for the world of research and scientific publications in Indonesia.
\end{abstract}

Keyword: Systematic Review, Literature Review, Dakwah, Islam, Indonesia

\section{A. Pendahuluan}

Pancasila, dasar negara Republik Indonesia, menegaskan bahwa Indonesia adalah negara yang berdasarkan atas Ketuhanan Yang Maha Esa. Meskipun tidak ada paksaan dalam meyakini agama (Q.S. Al-Baqarah [2]: 256), tetapi institusi Negara Kesatuan Republik Indonesia tidak mentoleransi warga negaranya yang ateis. Sejak 1945, pemerintahan yang sedang berkuasa selalu membentuk Departemen Agama sebagai ujung tombak untuk mengelola kebutuhan umat beragama dalam menjalankan keyakinannya. Departemen Agama sebagai perwujudan ulil amri (Q.S. AnNisaa [4]: 59) memformulasikan pedoman standar praktik kehidupan beragama untuk setiap agama yang diakui rezim pemerintahan yang 
sedang berkuasa. Konsekuensinya, ketika di tengah masyarakat muncul praktik-praktik kehidupan beragama yang tidak sejalan dengan pedoman yang dibuat pemerintah, maka praktik-praktik ini akan dianggap sebagai aliran sesat, misalnya kasus Ahmadiyah ${ }^{1}$. Kasus Hizbut Tahrir Indonesia (HTI) yang kontroversial adalah pengecualian. Meskipun HTI bukan aliran sesat, tetapi pemerintah menganggap aktivitas HTI tidak sejalan dengan ideologi Pancasila. Dalam perspektif pemerintah, aliran sesat atau yang dianggap bertentangan dengan ideologi Pancasila merupakan salah satu bentuk masalah sosial atau masalah publik yang menuntut intervensi pemerintah.

Pemerintah memang memiliki kemampuan mengendalikan institusi agama di ranah publik. Kemampuan ini ditopang dengan realitas kehidupan beragama di Indonesia yang masih melekat di ranah publik karena menjadi bagian dari kehidupan sehari-hari masyarakat. Dalam kasus Indonesia, situasi ini tidak bisa dilepaskan dari sejarah penyebaran agama Islam di Tanah Air dan pergulatan kaum muslimin dengan dinamika perubahan sosio-ekonomi masyarakat. Di saat bersamaan, praktik-praktik kehidupan beragama juga terjadi di ruang privat yang memberi seseorang akses relasi vertikal kepada Allah SWT (hablum minallah). Rasa percaya dan yakin kepada eksistensi Allah SWT diikuti dengan sikap taat terhadap perintah dan larangan-Nya yang termaktub dalam al-Quran menjadi fondasi bangunan relasi sosial horizontal (hablum minan nash) sesama individu, individu dengan kelompok, dan individu dengan beragam institusi sosial (Q.S. Ali Imron [3]: 112).

Dalam konteks hablum minan nash, orang beriman, apapun agamanya, ibarat berdiri tegak di titik tengah (median) sebuah garis lurus. Di ujung sebelah kiri, mereka berhadapan dengan para fundamentalisme yang dalam konteks Islam setara dengan istilah Islam radikal $^{2}$ dan terorisme Islam ${ }^{3}$ yang identik dengan kekerasan. Di ujung sebelah kanan,

${ }^{1}$ Burhani, Ahmad Najib. 2016. "Fundamentalism and Religious Dissent: The LPPI's Mission to Eradicate the Ahmadiyya in Indonesia." Indonesia and the Malay World 44 (129): 145-64.

http://dx.doi.org/10.1080/13639811.2015.1135610\%5Cnhttp://www.tandfonline.com/ doi/full/10.1080/13639811.2015.1135610.

2 Van Bruinessen, Martin. 2002. "Genealogioes of Islamic Radicalism in PostSoeharto Indonesia." South East Asia Research 10(2): 117-54.

3 Shughart II, William F. 2006. "An Analytical History of Terrorism, 1945-2000." Public Choice 128(1/2): 7-39.

402 JURNAL LISAN AL-HAL 
mereka berhadapan dengan para pendukung sekularisme yang, dalam konteks Islam, diwakili gerakan Islam liberal ${ }^{4}$. Meskipun ada jarak di antara fundamentalisme dan sekularisme, tetapi keduanya tetap terhubung dalam relasi simbiosis mutualisme ${ }^{5}$. Perkembangan keduanya juga tidak bersifat linear karena dipengaruhi faktor manipulasi politik ${ }^{6}$ Seperti ditunjukkan beberapa kasus kontemporer di Indonesia, misalnya "perda syariah", Front Pembela Islam (FPI), pembubaran Hizbut Tahrir Indonesia (HTI), pemblokiran aplikasi Telegram. Di antara fundamentalisme dan sekularisme, muncul istilah Islam Nusantara dan Islam moderat sebagai identitas agama Islam yang merupakan sekumpulan doktrin, praktik, komunitas, dan institusi ${ }^{7}$.

Karena pemerintah hanya mampu mengontrol kehidupan beragama di ruang publik, maka mereka membutuhkan partisipasi beragam organisasi non-pemerintah, baik para pelaku pasar yang berorientasi profit maupun lembaga swadaya masyarakat yang bergerak atas dasar prinsip keikhlasan (voluntary), untuk mengendalikan kehidupan beragama di ruang privat. Dalam konteks ini, karena dakwah bersifat fardhu ain (Q.S. Ali Imran [3]: 104; Q.S. An-Nahl [16]: 125), maka peran-peran dakwah bisa dilakukan pemerintah, korporasi swasta, dan masyarakat sipil. Pertanyaannya, seperti apa aktivitas dakwah yang sudah dilakukan ketiga aktor ini dalam konteks relasi segitiga di antara fundamentalisme, sekularisme, dan Islam Nusantara atau Islam moderat di Indonesia? Artikel ini dibuat untuk menjawab pertanyaan ini. Telaah pustaka difokuskan untuk menjelaskan aktor, jenis pesan, media, teknologi informasi dan komunikasi, dan kelompok sasaran dakwah. Tujuan akhirnya adalah mengonstruksi pengetahuan teoretis tentang aktivitas dakwah yang dilakukan aktor pemerintah, korporasi swasta, dan masyarakat sipil; serta memetakan research gap kajian tentang dakwah di Indonesia.

4 Muzakki, Akh. 2007. "Current Debates in the Post-Soeharto Indonesian Islam: Examining the Intelletual Base of Liberal and Anti-Liberal Islamic Movement." Al-Jami'ah: Journal of Islamic Studies 45(2): 321-66.

5 Armstrong, Karen. 2004. "Resisting Modernity: The Backlash Againts Secularism." Harvard International Review 25(4): 40-43.

${ }^{6}$ Von Der Mehden, Fred R. 1980. "Religion and Development in South-East Asia: A Comparative Study." World Development 8(7-8): 545-53.

7 Yapp, M. E. 2004. "Review Article: Islam and Islamism." Middle Eastern Studies 40(2): 161-82. 


\section{B. Metode}

Kami menggunakan pendekatan telaah pustaka (review literature) yang terdiri dua tahapan, yakni: (a) tahapan seleksi artikel; dan (b) tahapan analisis isi artikel. Tahapan seleksi artikel meliputi beberapa aktivitas, yakni: mengidentifikasi kata kunci penelusuran, memilih sumber database penelurusan, mengunduh dan mengelola full-text (.PDF) dan citation file (.RIS) dengan Mendeley (aplikasi manajemen referensi), merumuskan kriteria inclusion dan exclusion untuk menyaring hasil penelusuran agar bisa dilanjutkan ke tahapan analisis. Tahapan analisis isi artikel terdiri atas dua aktivitas, yakni analisis deskriptif dan analisis tematik. Analisis deskriptif meliputi proses pengolahan informasi bibliografi, metodologi, dan hasil penelitian. Sedangkan analisis tematik adalah telaah pustaka secara mendalam berdasarkan fokus yang ditetapkan peneliti.

\section{Hasil dan Pembahasan}

1. Tahapan seleksi artikel

Pustaka yang ditelaah adalah seluruh artikel ilmiah yang ditulis para sarjana yang di publikasikan di jurnal ilmiah yang terindeks di Directory Open Access Journal (DOAJ). Kami sengaja tidak memanfaatkan SCOPUS sebagai sumber penelusuran pustaka karena ingin melihat seberapa jauh para sarjana dan perguruan tinggi di Indonesia yang terkoneksi dengan gerakan Open Access berhasil mengonstruksi pengetahuan ilmiah tentang dakwah. Penelusuran artikel di DOAJ menggunakan basic search dengan kata dakwah sebagai kata kunci. Dengan kata kunci ini, kami meminta DOAJ menampilkan seluruh artikel yang mengandung kata dakwah, baik di judul, abstrak, dan kata kunci. Di putaran pertama, kami mendapatkan 288 artikel. Ketika hasil penelusuran ini disaring dengan "hanya menampilkan artikel”, DOAJ menampilkan 283 artikel. Hasil ini kemudian disaring lagi dengan kriteria "hanya menampilkan artikel yang mengandung kata dakwah di judul". Hasilnya, DOAJ menampilkan 94 artikel. 94 full-text artikel yang berbentuk .PDF kami unduh dan kelola dengan Mendeley. Kami menggunakan kriteria inclusion dan exclusion (lihat Tabel 1) untuk menyeleksi 94 artikel yang akan diikutsertakan dalam tahapan analisis isi artikel.

\footnotetext{
$404 \mid$ JURNAL LISAN AL-HAL
} 
Tabel 1 Kriteria Inclusion dan Exlusion

\begin{tabular}{|l|l|}
\hline Included & Excluded \\
\hline Empirical research & Review literature \\
\hline Peer-reviewed & Telaah pemikiran tokoh \\
\hline Ditulis dengan Bahasa & Tidak ditulis dengan Bahasa \\
Indonesia dan/atau Bahasa & Indonesia dan/atau Bahasa \\
Inggris & Inggris \\
\hline
\end{tabular}

\section{Tahapan Analisis Isi Artikel}

\section{a. Analisis Deskriptif}

Berdasarkan kriteria included dan excluded, kami memutuskan empat puluh empat artikel yang memenuhi kriteria untuk diikutsertakan dalam analisis deskriptif dan analisis tematik. Seperti ditunjukkan Tabel 2, empat puluh empat artikel ini terbit dalam kurun waktu 2004 - 2017. Tiga puluh empat perguruan tinggi pengelola jurnal yang menerbitkan jurnal sampel berada di bawah naungan Departemen Agama Republik Indonesia. Universitas Gadjah Mada (UGM) adalah satu-satu perguruan tinggi negeri di bawah Kementerian Riset, Teknologi, dan Pendidikan Tinggi yang termasuk dalam kategori perguruaan tinggi sampel. Hanya ada sembilan perguruan tinggi swasta di bawah Kemenristekdikti yang mengelola jurnal sampel penelitian ini. Secara geografis, sampel artikel ini berasal dari Bengkulu (1 artikel), Kalimantan Tengah (1 artikel), Kalimantan Timur (1 artikel), Lampung (1 artikel), Sulawesi Tengah (1 artikel), Sumatera Utara (1 artikel), Nangroe Aceh Darussalam (1 artikel), Sulawesi Tengah (1 artikel), Sumatera Utara (1 artikel), Daerah Istimewa Yogjakarta (3 artikel), Jawa Barat ( 4 artikel), Sumatera Selatan (4 artikel), Jawa Tengah (12 artikel), dan Jawa Timur (12 artikel). Gambaran sampel ini semakin menguatkan bahwa temuan penelitian ini dapat mencerminkan hasil penelitian tentang dakwah di Indonesia.

Dari sisi metodologis (lihat Tabel 3), dua puluh lima artikel merupakan hasil riset empiris yang menggunakan pendekatan kualitatif dengan beberapa variasi, misalnya kualitatif deskriptif, kualitatif fenomenologis, kualitatif historis, kualitatif etnografi. Hanya satu artikel yang menggunakan pendekatan kuantitatif dan dua artikel ditulis dengan pendekatan campuran mixed-methods. Tetapi, ada lima belas artikel yang tidak menjelaskan metode penelitian yang digunakan. Sumber data artikel meliputi karya seni (film, syair lagu, ukiran kaligrafi), dokumentasi 
sejarah, pegawai pemerintah, pegawai korporasi, objek virtual, pengurus masjid, pengurus pengajian, pelajar, mahasiswa, dan ulama. Ada lima belas artikel yang tidak mencantumkan secara jelas sumber data penelitian mereka. Teknik pengumpulan data yang digunakan para peneliti meliputi observasi, studi pustaka, dokumentasi, kuisioner, dan focus group discussion. Ada enam belas artikel yang tidak mencantumkan informasi tentang teknik pengumpulan data yang digunakan. Dalam aspek analisis data, para peneliti menggunakan beragam teknik analisis data, misalnya analisis media siber, analisis retorika, analisi SEM, analisis semiotika, content analysis, historiografi, interpretatif, kuantitatif deskriptif, analisis padan, model interaktif, textual analysis, dan verstehen. Ada dua puluh empat artikel yang tidak menjelaskan teknik analisis data yang digunakan dalam penelitian mereka. Dari empat puluh empat artikel sampel, hanya ada dua artikel yang menjelaskan teknik validasi data. Sisanya tidak ada yang mencantumkan informasi tentang proses validasi data.

Minimnya informasi tentang metode penelitian, khususnya sumber, teknik analisis dan validasi data, dalam sampel artikel mencerminkan rendahnya perhatian para peneliti terhadap pentingnya narasi metode penelitian dalam artikel ilmiah. Padahal, al-Quran secara implisit mengajarkan pentingnya metode dalam proses penelitian seperti ditunjukkan kisah Nabi Ibrahim a.s mencari Tuhan yang mengedepankan pendekatan positivisme, empirisme, dan logika induksi (QS. al-An'am [6] : 74-78). Metode positivisme juga digunakan Musa a.s di Bukit Tursina yang ingin memvalidasi keyakinannya soal eksistensi Tuhan (QS. Al-A'raf [7]: 143-147). Bahkan, variabel dan indikator penelitian (kuantitatif) atau lokus dan fokus (kualitatif) juga sudah diajarkan al-Quran melalui kisah penyembelihan sapi betina (Q.S al-Baqarah [2]: 67-73).

Adalah betul bahwa dalam konteks ilmu pengetahuan ilmiah, apa yang kita sebut dengan metode ilmiah, termasuk ilmu pengetahuan dan ilmuwan, hanyalah konvensi dan aturan main proses penemuan ilmu pengetahuan modern. Proses ini adalah permainan tanpa akhir. Jika pernyataan seseorang tidak perlu diverifikasi lagi, maka ujar, orang tersebut pensiun dari permainan ilmu pengetahuan. Dalam permainan ini, sebuah hipotesis atau pernyataan tidak boleh dikeluarkan dari permainan tanpa a good reason (alasan yang baik) yang dihasilkan proses falsification (falsifikasi). Konsekuensinya, ketika seseorang tidak menjelaskan metode yang digunakan untuk memproduksi beragam pernyataan ilmiahnya, 
maka ia sebetulnya tidak mengikuti aturan main penemuan ilmu pengetahuan modern. Kebenarannya dapat diragukan dan kontribusinya terhadap pertumbuhan ilmu pengetahuan ilmiah bisa diabaikan karena hipotesis/preposisinya tidak bisa diverifikasi dan difalsifikasi.

Meminjam istilah Khun, minimnya informasi perihal metode penelitian, khususnya sumber, teknik analisis dan validasi data, dalam sampel artikel dapat diinterpretasikan sebagai gejala anomali dalam dunia publikasi riset di Indonesia, khususnya komunitas para pengelola jurnal yang terindeks di DOAJ (Directory Open Access Journal). Faktanya, semua penerbit jurnal ilmiah bereputasi memberikan perhatian khusus terhadap aspek metode penelitian yang terkandung dalam artikel ilmiah, baik research paper maupun review paper.

Aspek lain yang perlu mendapatkan perhatian adalah dominasi pendekatan kualitatif deskriptif dalam studi dakwah di Indonesia. Deskripsi bertolak dari pertanyaan "how and what questions" yang menginterpretasikan fakta. Deskripsi (observasi, kategori, dan klasifikasi) hanya salah satu area pengetahuan ilmiah. Wilayah lainnya adalah generalisasi (generalisasi empiris, model, teori), seperti ditunjukkan dalam kisah Nabi Ibrahim a.s mencari Tuhan, yang bertolak dari 'why question' dan berusaha menjelaskan (explanation) relasi sebab akibat sekumpulan fakta sosial (Faye 2011; Schiffer 2013). Pengetahuan kausalitas ini, ujar Aristoteles, merupakan jenis pengetahuan yang superior (Psillos 2007, 100). Idealnya, studi dakwah tidak hanya dekriptif, tetapi eksplanatif dan prediktif sehingga pengetahuan teoretis yang dihasilkan tidak hanya membantu kita memahami fenomena, tetapi memberi peluang kepada kita memanipulasi fenomena untuk memaksimalkan 'perbuatan baik atas dasar iman', baik pada level individu maupun kolektif. Jika kita hanya berorientasi deskriptif, kami khawatir kita tidak akan pernah sampai pada titik pencerahan karena berhasil menarik kesimpulan seperti dialami Nabi Ibrahim a.s.

Explanation membutuhkan data empiris. Seperti ditunjukkan Tabel 3 , sumber data riset dakwah di Indonesia sangat beragam mulai dari karya seni (novel, lagu, film), pustaka, dokumen sejarah, dan objek virtual. Teknik pengumpulan data yang digunakan meliputi observasi, wawancara mendalam, kuisioner, studi pustaka, dokumentasi sebagai teknik pengumpulan data. Terkait dengan fakta ini, kami belum menemukan riset dakwah di Indonesia yang menggunakan big data, panel data, dan social 
"Telaah Literatur Dakwah Di Indonesia "

network sebagai sumber dan jenis data utama yang akan dianalisis untuk memahami perilaku $d a^{\prime} i$, mad'u, dan relasi keduanya dengan konteks dan struktur sosial meliputinya. Tentu saja, tiga jenis data ini membutuhkan seperangkat kompetensi teknis pengolahan data dan sudut pandang teoritis agar ia mejadi lebih bermakna.

408 JURNAL LISAN AL-HAL 
Tabel 2 Sebaran artikel yang ditelaah berdasarkan nama penulis, nama jurnal, tahun terbit, penerbit, dan status perguruan tinggi

\begin{tabular}{|c|c|c|c|c|}
\hline No. & Penulis & Nama jurnal & Penerbit & Status Perguruan Tinggi \\
\hline 1 & Abdurrazaq (2013) & Intizar & UIN Raden Fatah, Sumatera Selatan & PTN Kemenag \\
\hline 2 & Arsam (2014) & ADDIN & STAIN Kudus, Jawa Timur & PTN Kemenag \\
\hline 3 & Bandarsyah (2016) & Jurnal Historia & Universitas Muhammadiyah Metro, Lampung & PTS Dikti \\
\hline 4 & $\begin{array}{l}\text { Bin Sanusi and } \\
\text { Mohamed (2017) }\end{array}$ & Jurnal Ilmiah Islam Futura & UIN ar-Raniry, Nangroe Aceh Darussalam & PTN Kemenag \\
\hline 5 & Bukhari (2015) & MIQOT & UIN Sumatera Utara, Sumatera Utara & PTN Kemenag \\
\hline 6 & Choiriyah (2013) & Intizar & UIN Raden Fatah, Sumatera Selatan & PTN Kemenag \\
\hline 7 & Dalmeri (2014) & $\begin{array}{l}\text { Walisongo: Jurnal Penelitian } \\
\text { Sosial dan Keagamaan }\end{array}$ & UIN Walisongo, Jawa Tengah & PTN Kemenag \\
\hline 8 & $\begin{array}{l}\text { Dwiningrum } \\
(2014)\end{array}$ & $\begin{array}{l}\text { Walisongo: Jurnal Penelitian } \\
\text { Sosial dan Keagamaan }\end{array}$ & UIN Walisongo, Jawa Tengah & PTN Kemenag \\
\hline 9 & $\begin{array}{l}\text { Diania and } \\
\text { Fatmawati (2016) }\end{array}$ & Madania & IAIN Bengkulu, Bengkulu & PTN Kemenag \\
\hline 10 & Haryanto (2016) & $\begin{array}{l}\text { Jurnal Studi Agama dan } \\
\text { Masyarakat }\end{array}$ & IAIN Palangkaraya, Kalimantan Tengah & PTN Kemenag \\
\hline 11 & Hayat (2014) & $\begin{array}{l}\text { Walisongo: Jurnal Penelitian } \\
\text { Sosial dan Keagamaan }\end{array}$ & UIN Walisongo, Jawa Tengah & PTN Kemenag \\
\hline 12 & Hidayanti (2014) & $\begin{array}{l}\text { KONSELING RELIGI: Jurnal } \\
\text { Bimbingan Konseling Islam }\end{array}$ & STAIN Kudus, Jarim & PTN Kemenag \\
\hline 13 & $\begin{array}{l}\text { Hun and Hassan } \\
\text { (2017) }\end{array}$ & $\begin{array}{l}\text { Indonesian Language } \\
\text { Education and Literature } \\
\text { (ILEAL) }\end{array}$ & IAIN Syekh Nurjati, Jawa Barat & PTN Kemenag \\
\hline 14 & Isnaniah (2013) & KARSA & STAIN Pamekasan, Jawa Timur & PTN Kemenag \\
\hline 15 & Jalil (2016) & $\begin{array}{l}\text { Walisongo: Jurnal Penelitian } \\
\text { Sosial dan Keagamaan }\end{array}$ & UIN Walisongo, Jawa Tengah & PTN Kemenag \\
\hline 16 & Kholili \& Hadi & Kawistara & UGM, Jogjakarta & PTN Dikti \\
\hline
\end{tabular}


"Telaah Literatur Dakwah Di Indonesia "

\begin{tabular}{|c|c|c|c|c|}
\hline & $(2014)$ & & & \\
\hline 17 & $\begin{array}{l}\text { Kusuma and } \\
\text { Octastefani (2017) }\end{array}$ & $\begin{array}{l}\text { al-Balagh: Jurnal Dakwah } \\
\text { dan Komunikasi }\end{array}$ & IAIN Surakarta, Jawa Tengah & PTN Kemenag \\
\hline 18 & Latief (2012) & Journal of Indonesian Islam & UIN Sunan Ampel, Jawa Timur & PTN Kemenag \\
\hline 19 & Ma'arif (2011) & Mimbar & Universitas Islam Bandung, Jawa Barat & PTS Dikti \\
\hline 20 & Ma'arif (2009) & Mimbar & Universitas Islam Bandung, Jawa Barat & PTS Dikti \\
\hline 21 & Masmuddin (2017) & $\begin{array}{l}\text { Hunafa: Jurnal Studia } \\
\text { Islamika }\end{array}$ & IAIN Palu, Sulawesi Tengah & PTN Kemenag \\
\hline 22 & Najitama (2016) & El Harakah & UIN Maulana Malik Ibrahim, Jawa Timur & PTN Kemenag \\
\hline 23 & Nasrullah (2016) & El Harakah & UIN Maulana Malik Ibrahim, Jawa Timur & PTN Kemenag \\
\hline 24 & (Novaili 2015) & El Harakah & UIN Maulana Malik Ibrahim, Jawa Timur & PTN Kemenag \\
\hline 25 & Nura'ini (2013) & $\begin{array}{l}\text { PROFETIKA: Jurnal Studi } \\
\text { Islam }\end{array}$ & Universitas Muhammadiyah Solo, Jawa Tengah & PTS Dikti \\
\hline 26 & Pahlevi (2016) & Intizar & UIN Raden Fatah, Sumatera Selatan & PTN Kemenag \\
\hline 27 & $\begin{array}{l}\text { Rachmiatie, Sidik, \& } \\
\text { Farihat (2004) }\end{array}$ & $\begin{array}{l}\text { PROFETIKA: Jurnal Studi } \\
\text { Islam }\end{array}$ & Universitas Muhammadiyah Solo, Jawa Tengah & PTS Dikti \\
\hline 28 & Raihan (2015) & Jurnal Ilmiah Islam Futura & UIN ar-Raniry, Nangroe Aceh Darussalam & PTN Kemenag \\
\hline 29 & Razzaq (2014) & Intizar & UIN Raden Fatah, Sumatera Selatan & PTN Kemenag \\
\hline 30 & Riyadi (2014) & $\begin{array}{l}\text { KONSELING RELIGI: Jurnal } \\
\text { Bimbingan Konseling Islam }\end{array}$ & STAIN Kudus, Jawa Timur & PTN Kemenag \\
\hline 31 & Rosa (2014) & $\begin{array}{l}\text { Walisongo: Jurnal Penelitian } \\
\text { Sosial dan Keagamaan }\end{array}$ & UIN Walisongo, Jawa Tengah & PTN Kemenag \\
\hline 32 & Saifulah (2014) & $\begin{array}{l}\text { Islamica: Jurnal Studi } \\
\text { Keislaman }\end{array}$ & UIN Sunan Ampel, Jawa Timur & PTN Kemenag \\
\hline 33 & Shobron (2014) & $\begin{array}{l}\text { PROFETIKA: Jurnal Studi } \\
\text { Islam }\end{array}$ & Universitas Muhammadiyah Solo, Jawa Tengah & PTS Dikti \\
\hline 34 & $\begin{array}{l}\text { Shobron, Rosyadi, } \\
\text { \& Suaidy (2015) }\end{array}$ & $\begin{array}{l}\text { PROFETIKA: Jurnal Studi } \\
\text { Islam }\end{array}$ & Universitas Muhammadiyah Solo, Jawa Tengah & PTS Dikti \\
\hline
\end{tabular}

$410 \mid$ JURNAL LISAN AL-HAL 


\begin{tabular}{|c|c|c|c|c|}
\hline 35 & Shodiq (2015) & $\begin{array}{l}\text { PROFETIKA: Jurnal Studi } \\
\text { Islam }\end{array}$ & Universitas Muhammadiyah Solo, Jawa Tengah & PTS Dikti \\
\hline 36 & Sofjan (2012) & Al-Jami'ah & UIN Sunan Kalijaga, Jogjakarta & PTN Kemenag \\
\hline 37 & Sukardi (2014) & Jurnal Ilmiah Islam Futura & UIN ar-Raniry, Nangroe Aceh Darussalam & PTN Kemenag \\
\hline 38 & Sunarwoto (2012) & Al-Jami'ah & UIN Sunan Kalijaga, Jogjakarta & PTN Kemenag \\
\hline 39 & Susanto (2013) & $\begin{array}{l}\text { KONSELING RELIGI: Jurnal } \\
\text { Bimbingan Konseling Islam }\end{array}$ & STAIN Kudus, Jawa Timur & PTN Kemenag \\
\hline 40 & Susanto (2014) & $\begin{array}{l}\text { KONSELING RELIGI: Jurnal } \\
\text { Bimbingan Konseling Islam }\end{array}$ & STAIN Kudus, Jawa Timur & PTN Kemenag \\
\hline 41 & Syobah (2015) & Fenomena & IAIN Samarinda, Kalimantan Timur & PTN Kemenag \\
\hline 42 & Ubaidillah (2015) & $\begin{array}{l}\text { IBDA': Jurnal Kebudayaan } \\
\text { Islam }\end{array}$ & IAIN Purwokerto, Jawa Tengah & PTN Kemenag \\
\hline 43 & $\begin{array}{l}\text { Wahyuningsih } \\
\text { (2013) }\end{array}$ & KARSA & STAIN Kudus, Jawa Timur & PTN Kemenag \\
\hline 44 & Yusuf (2016) & Mediator & Universitas Islam Bandung, Jawa Barat & PTS Dikti \\
\hline
\end{tabular}

Tabel 3 Sebaran artikel berdasarkan penulis, tahun terbit, jenis penelitian, sumber data, teknik pengumpulan, analisis, dan validasi data

\begin{tabular}{|c|l|c|l|l|l|l|l|}
\hline No. & Penulis & Tahun & Jenis penelitian & Sumber data & $\begin{array}{l}\text { Teknik } \\
\text { pengumpulan data }\end{array}$ & $\begin{array}{l}\text { Teknik } \\
\text { analisis data }\end{array}$ & $\begin{array}{l}\text { Teknik } \\
\text { validasi data }\end{array}$ \\
\hline 1 & Abdurrazaq & 2013 & Kualitatif deskriptif & $\begin{array}{l}\text { Tiga novel karya } \\
\text { Habiburrahman El } \\
\text { Shirazi }\end{array}$ & $\begin{array}{l}\text { Informasi tidak } \\
\text { tersedia } \\
\text { analysis }\end{array}$ \\
\hline 2 & Arsam & 2014 & Kualitatif deskriptif & Takmir masjid & $\begin{array}{l}\text { Observasi, } \\
\text { wawancara, dan } \\
\text { dokumentasi }\end{array}$ & $\begin{array}{l}\text { Informasi } \\
\text { tidak tersedia }\end{array}$ & $\begin{array}{l}\text { Informasi tidak } \\
\text { tersedia }\end{array}$ \\
\hline 3 & Bandarsyah & 2016 & $\begin{array}{l}\text { Informasi tidak } \\
\text { tersedia }\end{array}$ & Data sekunder & Studi pustaka & $\begin{array}{l}\text { Informasi } \\
\text { tidak tersedia }\end{array}$ & $\begin{array}{l}\text { Informasi tidak } \\
\text { tersedia }\end{array}$ \\
\hline 4 & Bin Sanusi & 2017 & Kualitatif deskriptif & Data sekunder & Studi pustaka & Informasi & Informasi tidak \\
\hline
\end{tabular}


"Telaah Literatur Dakwah Di Indonesia "

\begin{tabular}{|c|c|c|c|c|c|c|c|}
\hline & \& Mohamed & & & & & tidak tersedia & tersedia \\
\hline 5 & Bukhari & 2015 & $\begin{array}{l}\text { Kualitatif } \\
\text { fenomenologis }\end{array}$ & $\begin{array}{l}\text { Mad'u dan pengurus } \\
\text { masjid }\end{array}$ & $\begin{array}{l}\text { Observasi, } \\
\text { wawancara, dan } \\
\text { dokumentasi }\end{array}$ & $\begin{array}{l}\text { Informasi } \\
\text { tidak tersedia }\end{array}$ & $\begin{array}{l}\text { Informasi tidak } \\
\text { tersedia }\end{array}$ \\
\hline 6 & Choiriyah & 2013 & Kualitatif deskriptif & Syair lagu & Studi pustaka & $\begin{array}{l}\text { Content } \\
\text { analysis }\end{array}$ & $\begin{array}{l}\text { Informasi tidak } \\
\text { tersedia }\end{array}$ \\
\hline 7 & Dalmeri & 2014 & Kualitatif deskriptif & Data sekunder & $\begin{array}{l}\text { Observasi, } \\
\text { wawancara, dan } \\
\text { dokumentasi }\end{array}$ & $\begin{array}{l}\text { Informasi } \\
\text { tidak tersedia }\end{array}$ & $\begin{array}{l}\text { Informasi tidak } \\
\text { tersedia }\end{array}$ \\
\hline 8 & $\begin{array}{l}\text { Dwiningru } \\
\mathrm{m}\end{array}$ & 2014 & Kualitatif deskriptif & Informasi tidak tersedia & $\begin{array}{l}\text { Informasi tidak } \\
\text { tersedia }\end{array}$ & $\begin{array}{l}\text { Informasi } \\
\text { tidak tersedia }\end{array}$ & $\begin{array}{l}\text { Informasi tidak } \\
\text { tersedia }\end{array}$ \\
\hline 9 & $\begin{array}{l}\text { Fatmawati } \\
\text { \& Diania }\end{array}$ & 2016 & $\begin{array}{l}\text { Kualitatif (studi } \\
\text { pustaka) }\end{array}$ & Data sekunder & Studi pustaka & $\begin{array}{l}\text { Model } \\
\text { interaktif }\end{array}$ & $\begin{array}{l}\text { Informasi tidak } \\
\text { tersedia }\end{array}$ \\
\hline 10 & Haryanto & 2016 & $\begin{array}{l}\text { Kuantitatif } \\
\text { deskriptif }\end{array}$ & Data sekunder & Studi pustaka & $\begin{array}{l}\text { Content } \\
\text { analysis }\end{array}$ & $\begin{array}{l}\text { Informasi tidak } \\
\text { tersedia }\end{array}$ \\
\hline 11 & Hayat & 2014 & $\begin{array}{l}\text { Kualitatif (studi } \\
\text { pustaka) }\end{array}$ & Data sekunder & Studi pustaka & $\begin{array}{l}\text { Informasi } \\
\text { tidak tersedia }\end{array}$ & $\begin{array}{l}\text { Informasi tidak } \\
\text { tersedia }\end{array}$ \\
\hline 12 & Hidayanti & 2014 & $\begin{array}{l}\text { Informasi tidak } \\
\text { tersedia }\end{array}$ & Informasi tidak tersedia & $\begin{array}{l}\text { Informasi tidak } \\
\text { tersedia }\end{array}$ & $\begin{array}{l}\text { Informasi } \\
\text { tidak tersedia }\end{array}$ & $\begin{array}{l}\text { Informasi tidak } \\
\text { tersedia }\end{array}$ \\
\hline 13 & $\begin{array}{l}\text { Hun \& Abu } \\
\text { Hasan }\end{array}$ & 2017 & $\begin{array}{l}\text { Kualitatif (studi } \\
\text { pustaka) }\end{array}$ & Novel AAC 2 & Studi pustaka & $\begin{array}{l}\text { Content } \\
\text { analysis }\end{array}$ & $\begin{array}{l}\text { Informasi tidak } \\
\text { tersedia }\end{array}$ \\
\hline 14 & Isnania & 2013 & Kualitatif deskriptif & $\begin{array}{l}\text { Para aktivis dakwah } \\
\text { kampus }\end{array}$ & $\begin{array}{l}\text { Interview dan } \\
\text { analisis dokumen }\end{array}$ & $\begin{array}{l}\text { Model } \\
\text { interaktif }\end{array}$ & $\begin{array}{l}\text { triangulasi } \\
\text { metode, } \\
\text { sumber data, } \\
\text { dan review } \\
\text { informan }\end{array}$ \\
\hline
\end{tabular}

412 JURNAL LISAN AL-HAL 


\begin{tabular}{|c|c|c|c|c|c|c|c|}
\hline 15 & Jalil & 2014 & Kualitatif deskriptif & $\begin{array}{l}\text { Data primer dan } \\
\text { sekunder }\end{array}$ & $\begin{array}{l}\text { Observasi, } \\
\text { wawancara, dan } \\
\text { dokumentasi }\end{array}$ & $\begin{array}{l}\text { Informasi } \\
\text { tidak tersedia }\end{array}$ & $\begin{array}{l}\text { Informasi tidak } \\
\text { tersedia }\end{array}$ \\
\hline 16 & $\begin{array}{l}\text { Kholili \& } \\
\text { Hadi }\end{array}$ & 2014 & Mixed method & $\begin{array}{l}303 \text { orang kelompok } \\
\text { binaan; } 29 \text { orang PAIF }\end{array}$ & $\begin{array}{l}\text { Kuisioner dan } \\
\text { wawancara }\end{array}$ & $\begin{array}{l}\text { Analisis SEM } \\
\text { dan kualitatif }\end{array}$ & $\begin{array}{l}\text { Informasi tidak } \\
\text { tersedia }\end{array}$ \\
\hline 17 & $\begin{array}{l}\text { Kusuma \& } \\
\text { Octastefani }\end{array}$ & 2017 & Kualitatif deskriptif & Data sekunder & Studi pustaka & $\begin{array}{l}\text { Model } \\
\text { interaktif }\end{array}$ & $\begin{array}{l}\text { Informasi tidak } \\
\text { tersedia }\end{array}$ \\
\hline 18 & Latief & 2012 & $\begin{array}{l}\text { Informasi tidak } \\
\text { tersedia }\end{array}$ & Informasi tidak tersedia & $\begin{array}{l}\text { Informasi tidak } \\
\text { tersedia }\end{array}$ & $\begin{array}{l}\text { Informasi } \\
\text { tidak tersedia }\end{array}$ & $\begin{array}{l}\text { Informasi tidak } \\
\text { tersedia }\end{array}$ \\
\hline 19 & Ma'arif & 2011 & Kualitatif deskriptif & $\begin{array}{l}\text { Aktivis jemaah pengajian } \\
\text { KH. Abdullah Gymnastiar } \\
\text { dan KH. Jalaludin } \\
\text { Rahmat }\end{array}$ & $\begin{array}{l}\text { Studi pustaka, } \\
\text { wawancara } \\
\text { mendalam, dan } \\
\text { observasi }\end{array}$ & $\begin{array}{l}\text { Analisis } \\
\text { retorika }\end{array}$ & $\begin{array}{l}\text { Informasi tidak } \\
\text { tersedia }\end{array}$ \\
\hline 20 & Ma'arif & 2009 & Kualitatif deskriptif & $\begin{array}{l}\text { Data sekunder dan } \\
\text { primer }\end{array}$ & $\begin{array}{l}\text { Studi pustaka dan } \\
\text { wawancara } \\
\text { mendalam }\end{array}$ & $\begin{array}{l}\text { Analisis } \\
\text { retorika }\end{array}$ & $\begin{array}{l}\text { Informasi tidak } \\
\text { tersedia }\end{array}$ \\
\hline 21 & Masmuddin & 2014 & Kualitatif deskriptif & Tokoh agama & $\begin{array}{l}\text { Studi pustaka dan } \\
\text { wawancara } \\
\text { mendalam }\end{array}$ & $\begin{array}{l}\text { Informasi } \\
\text { tidak tersedia }\end{array}$ & $\begin{array}{l}\text { Informasi tidak } \\
\text { tersedia }\end{array}$ \\
\hline 22 & Najitama & 2016 & $\begin{array}{l}\text { Kualitatif } \\
\text { interpretatif }\end{array}$ & $\begin{array}{l}\text { Pengurus dan anggota } \\
\text { komunitas Padasuka }\end{array}$ & $\begin{array}{l}\text { Observasi, } \\
\text { wawancara, dan } \\
\text { dokumentasi }\end{array}$ & Interpretatif & $\begin{array}{l}\text { Informasi tidak } \\
\text { tersedia }\end{array}$ \\
\hline 23 & Nasrullah & 2016 & Kualitatif etnografi & Objek virtual (meme) & $\begin{array}{l}\text { Observasi, studi } \\
\text { pustaka, } \\
\text { dokumentasi }\end{array}$ & $\begin{array}{l}\text { Analisis media } \\
\text { siber }\end{array}$ & $\begin{array}{l}\text { Informasi tidak } \\
\text { tersedia }\end{array}$ \\
\hline 24 & Novaili & 2016 & $\begin{array}{l}\text { Informasi tidak } \\
\text { tersedia }\end{array}$ & Informasi tidak tersedia & $\begin{array}{l}\text { Informasi tidak } \\
\text { tersedia }\end{array}$ & $\begin{array}{l}\text { Informasi } \\
\text { tidak tersedia }\end{array}$ & $\begin{array}{l}\text { Informasi tidak } \\
\text { tersedia }\end{array}$ \\
\hline 25 & Nur'aini & 2013 & Kualitatif historis & Data sekunder & Studi pustaka & Historiografi & Informasi tidak \\
\hline
\end{tabular}


"Telaah Literatur Dakwah Di Indonesia "

\begin{tabular}{|c|c|c|c|c|c|c|c|}
\hline & & & & & & & tersedia \\
\hline 26 & Pahlevi & 2016 & $\begin{array}{l}\text { Informasi tidak } \\
\text { tersedia }\end{array}$ & Informasi tidak tersedia & $\begin{array}{l}\text { Informasi tidak } \\
\text { tersedia }\end{array}$ & $\begin{array}{l}\text { Informasi } \\
\text { tidak tersedia }\end{array}$ & $\begin{array}{l}\text { Informasi tidak } \\
\text { tersedia }\end{array}$ \\
\hline 27 & $\begin{array}{l}\text { Rachmiatie, } \\
\text { Sidik, \& } \\
\text { Farihat }\end{array}$ & 2004 & Mixed method & Siswa SMU & $\begin{array}{l}\text { Wawancara dan } \\
\text { kuisioner }\end{array}$ & $\begin{array}{l}\text { Kuantitatif } \\
\text { deskriptif }\end{array}$ & $\begin{array}{l}\text { Informasi tidak } \\
\text { tersedia }\end{array}$ \\
\hline 28 & Raihan & 2015 & $\begin{array}{l}\text { Informasi tidak } \\
\text { tersedia }\end{array}$ & Informasi tidak tersedia & $\begin{array}{l}\text { Informasi tidak } \\
\text { tersedia }\end{array}$ & $\begin{array}{l}\text { Informasi } \\
\text { tidak tersedia }\end{array}$ & $\begin{array}{l}\text { Informasi tidak } \\
\text { tersedia }\end{array}$ \\
\hline 29 & Razzaq & 2014 & $\begin{array}{l}\text { Informasi tidak } \\
\text { tersedia }\end{array}$ & Informasi tidak tersedia & $\begin{array}{l}\text { Informasi tidak } \\
\text { tersedia }\end{array}$ & $\begin{array}{l}\text { Informasi } \\
\text { tidak tersedia }\end{array}$ & $\begin{array}{l}\text { Informasi tidak } \\
\text { tersedia }\end{array}$ \\
\hline 30 & Riyadi & 2014 & $\begin{array}{l}\text { Informasi tidak } \\
\text { tersedia }\end{array}$ & Informasi tidak tersedia & $\begin{array}{l}\text { Informasi tidak } \\
\text { tersedia }\end{array}$ & $\begin{array}{l}\text { Informasi } \\
\text { tidak tersedia }\end{array}$ & $\begin{array}{l}\text { Informasi tidak } \\
\text { tersedia }\end{array}$ \\
\hline 31 & Rosa & 2014 & $\begin{array}{l}\text { Informasi tidak } \\
\text { tersedia }\end{array}$ & Informasi tidak tersedia & $\begin{array}{l}\text { Informasi tidak } \\
\text { tersedia }\end{array}$ & $\begin{array}{l}\text { Informasi } \\
\text { tidak tersedia }\end{array}$ & $\begin{array}{l}\text { Informasi tidak } \\
\text { tersedia }\end{array}$ \\
\hline 32 & Saifullah & 2014 & $\begin{array}{l}\text { Informasi tidak } \\
\text { tersedia }\end{array}$ & Informasi tidak tersedia & $\begin{array}{l}\text { Informasi tidak } \\
\text { tersedia }\end{array}$ & $\begin{array}{l}\text { Informasi } \\
\text { tidak tersedia }\end{array}$ & $\begin{array}{l}\text { Informasi tidak } \\
\text { tersedia }\end{array}$ \\
\hline 33 & Shobron & 2014 & Kualitatif historis & Data sekunder & $\begin{array}{l}\text { Studi pustaka dan } \\
\text { dokumentasi }\end{array}$ & Verstehen & $\begin{array}{l}\text { Informasi tidak } \\
\text { tersedia }\end{array}$ \\
\hline 34 & $\begin{array}{l}\text { Shobron, } \\
\text { Rosyadi, \& } \\
\text { Suaidy }\end{array}$ & 2015 & $\begin{array}{l}\text { Kualitatif } \\
\text { fenomenologis }\end{array}$ & $\begin{array}{l}\text { Pengurus pondok } \\
\text { pesantren }\end{array}$ & $\begin{array}{l}\text { Observasi, } \\
\text { wawancara, dan } \\
\text { dokumentasi }\end{array}$ & $\begin{array}{l}\text { Model } \\
\text { interaktif }\end{array}$ & $\begin{array}{l}\text { Informasi tidak } \\
\text { tersedia }\end{array}$ \\
\hline 35 & Shodiq & 2015 & $\begin{array}{l}\text { Informasi tidak } \\
\text { tersedia }\end{array}$ & Informasi tidak tersedia & $\begin{array}{l}\text { Informasi tidak } \\
\text { tersedia }\end{array}$ & $\begin{array}{l}\text { Informasi } \\
\text { tidak tersedia }\end{array}$ & $\begin{array}{l}\text { Informasi tidak } \\
\text { tersedia }\end{array}$ \\
\hline 36 & Sofjan & 2012 & $\begin{array}{l}\text { Kualitatif (studi } \\
\text { kasus) }\end{array}$ & $\begin{array}{l}\text { Jemaah pengajian } \\
\text { mamah Dede }\end{array}$ & $\begin{array}{l}\text { Observasi, } \\
\text { wawancara, } \\
\text { dokumentasi, dan }\end{array}$ & $\begin{array}{l}\text { Textual } \\
\text { analysis }\end{array}$ & $\begin{array}{l}\text { Informasi tidak } \\
\text { tersedia }\end{array}$ \\
\hline
\end{tabular}

$414 \mid$ JURNAL LISAN AL-HAL 


\begin{tabular}{|c|c|c|c|c|c|c|c|}
\hline & & & & & FGD & & \\
\hline 37 & Sukardi & 2014 & $\begin{array}{l}\text { Informasi tidak } \\
\text { tersedia }\end{array}$ & Informasi tidak tersedia & $\begin{array}{l}\text { Informasi tidak } \\
\text { tersedia }\end{array}$ & $\begin{array}{l}\text { Informasi } \\
\text { tidak tersedia }\end{array}$ & $\begin{array}{l}\text { Informasi tidak } \\
\text { tersedia }\end{array}$ \\
\hline 38 & Sunarwoto & 2014 & $\begin{array}{l}\text { Informasi tidak } \\
\text { tersedia }\end{array}$ & Informasi tidak tersedia & $\begin{array}{l}\text { Informasi tidak } \\
\text { tersedia }\end{array}$ & $\begin{array}{l}\text { Informasi } \\
\text { tidak tersedia }\end{array}$ & $\begin{array}{l}\text { Informasi tidak } \\
\text { tersedia }\end{array}$ \\
\hline 39 & Susanto & 2013 & Kualitatif deskriptif & Informasi tidak tersedia & $\begin{array}{l}\text { Informasi tidak } \\
\text { tersedia }\end{array}$ & $\begin{array}{l}\text { Informasi } \\
\text { tidak tersedia }\end{array}$ & $\begin{array}{l}\text { Informasi tidak } \\
\text { tersedia }\end{array}$ \\
\hline 40 & Susanto & 2014 & $\begin{array}{l}\text { Informasi tidak } \\
\text { tersedia }\end{array}$ & Informasi tidak tersedia & $\begin{array}{l}\text { Informasi tidak } \\
\text { tersedia }\end{array}$ & $\begin{array}{l}\text { Informasi } \\
\text { tidak tersedia }\end{array}$ & $\begin{array}{l}\text { Informasi tidak } \\
\text { tersedia }\end{array}$ \\
\hline 41 & Syobah & 2015 & Kualitatif deskriptif & $\begin{array}{l}\text { Bagi produksi acara } \\
\text { dakwah TVRI Kaltim }\end{array}$ & $\begin{array}{l}\text { Observasi, studi } \\
\text { pustaka, } \\
\text { dokumentasi }\end{array}$ & $\begin{array}{l}\text { Model } \\
\text { interaktif }\end{array}$ & $\begin{array}{l}\text { Triangulasi } \\
\text { sumber data }\end{array}$ \\
\hline 42 & Ubaidillah & 2015 & Kualitatif & $\begin{array}{l}\text { Sepuluh arsip surat Nabi } \\
\text { Muhammad SAW }\end{array}$ & Studi pustaka & $\begin{array}{l}\text { Metode } \\
\text { analisis padan }\end{array}$ & $\begin{array}{l}\text { Informasi tidak } \\
\text { tersedia }\end{array}$ \\
\hline 43 & $\begin{array}{l}\text { Wahyuning } \\
\text { sih }\end{array}$ & 2013 & Kualitatif & Film Ayat-ayat Cinta & $\begin{array}{l}\text { Dokumentasi, studi } \\
\text { pustaka, wawancara } \\
\text { mendalam }\end{array}$ & $\begin{array}{l}\text { Analisis } \\
\text { semiotika }\end{array}$ & $\begin{array}{l}\text { Informasi tidak } \\
\text { tersedia }\end{array}$ \\
\hline 44 & Yusuf & 2016 & $\begin{array}{l}\text { Informasi tidak } \\
\text { tersedia }\end{array}$ & Informasi tidak tersedia & $\begin{array}{l}\text { Informasi tidak } \\
\text { tersedia }\end{array}$ & $\begin{array}{l}\text { Informasi } \\
\text { tidak tersedia }\end{array}$ & $\begin{array}{l}\text { Informasi tidak } \\
\text { tersedia }\end{array}$ \\
\hline
\end{tabular}


Kami mengklasifikasikan tujuan penelitian ke dalam empat kategori, yakni: pesan dakwah, manajemen dakwah, organisasi dakwah, dan praktik dakwah. Klasifikasi ini, tentu saja, sangat subyektif karena tergantung dengan tujuan setiap penelitian. Karena telaah pustaka ini bertujuan mengonstruksi pengetahuan teoretis tentang aktivitas dakwah para da'i (pemerintah, korporasi swasta, dan masyarakat sipil) dan memetakan research gap kajian tentang dakwah di Indonesia, maka kategorisasi yang kami buat merupakan wujud pengetahuan teoritis yang dihasilkan penelitian ini. Jika Tabel 4 dikuantifikasi, maka berdasarkan hasil koding yang dilakukan peneliti, empat puluh empat artikel yang ditelaah bisa dikelompokkan berdasarkan empat kategori, yakni: manajemen dakwah (11 persen), organisasi dakwah (20 persen), pesan dakwah (30 persen), dan praktik dakwah (39 persen). Dari jumlah total artikel sampel, hanya satu artikel yang memberikan informasi tentang kelemahan penelitian dan menawarkan agenda penelitian selanjutnya.

Dominasi kajian tentang praktik dakwah (39 persen) menunjukkan bahwa Indonesia sebetulnya memiliki data empiris yang sangat kaya tentang fenomena dakwah. Tetapi, seperti ditunjukkan kategori pesan dakwah (30 persen), kajian dakwah cenderung dianggap sebagai kajian disiplin ilmu komunikasi. Padahal, konsep dan praktik dakwah sendiri lebih luas jika dibandingkan dengan definisi komunikasi. Komunikasi hanya salah satu bagian dakwah. Dengan sudut pandang seperti ini, langkah beberapa peneliti di Indonesia, misalnya Bukhari (2015), Kusuma and Octastefani (2017), Latief (2012), Najitama (2016), Nasrullah (2016), Riyadi (2014), Rosa (2014), Sofjan (2012), Shodiq (2015), Susanto (2014), Shobron, Rosyadi, \& Suaidy (2015), dan Yusuf (2016), yang berusaha memahami fenomena dakwah dengan sudut pandang teoretis yang berbeda perlu diapresiasi dan terus dilanjutkan.

Sementara itu, kami mengelompokkan hasil penelitian ke dalam beberapa kategori. Pengelompokkan ini didasarkan atas pertimbangan subyektif penulis tentang isu dan fenomena yang perlu mendapatkan perhatian lebih jauh dari para peneliti dakwah di Indonesia. Beberapa isu tersebut adalah akuntabilitas dakwah (Arsam 2014), karya seni sebagai pembungkus pesan dakwah (Abdurrazaq 2013; Choiriyah 2013; Hun and Hassan 2017; Pahlevi 2016; Bin Sanusi and Mohamed 2017; Wahyuningsih 2013), bentuk dan alur informasi di media sosial (Nasrullah 2016), kesetaraan gender (Nura'ini 2013; Sofjan 2012), modernitas

416 JURNAL LISAN AL-HAL 
(Bandarsyah 2016), pengobatan sebagai instrumen dakwah (Hidayanti 2014; Riyadi 2014; Susanto 2013, 2014), revitalisasi fungsi masjid (Dalmeri 2014; Haryanto 2016), pesan inklusif dan dakwah multikultural (Dwiningrum 2014; Ma'arif 2011; Saifulah 2014), perubahan strategi dakwah (Diania and Fatmawati 2016), resistensi dan adaptasi komunitas Islam kultural (Bukhari 2015; Hayat 2014; Najitama 2016; Shodiq 2015; Yusuf 2016), birokrasi publik sebagai instrumen dakwah (Kholili and Hadi 2014; Novaili 2015), aktivitas filantropi korporasi swasta dan masyarakat sipil (Latief 2012; Razzaq 2014), politisasi dakwah (Kusuma and Octastefani 2017; Rosa 2014), dan efektivitas lembaga penyiaran konvensional (Rachmiatie, Sidik, and Farihat 2004; Sunarwoto 2012; Syobah 2015).

Aspek lain yang kurang mendapatkan perhatian dari penulis artikel adalah perihal limitasi penelitian dan agenda penelitian selanjutnya. Dari total sampel artikel, hanya artikel Bukhari (2015) yang mengandung informasi dua aspek ini. Padahal, narasi limitasi penelitian merupakan pintu masuk untuk memahami temuan riset secara kontekstual, validitas dan kredibilitas kesimpulan penelitian (Ioannidis 2007). Sementara itu, tawaran agenda penelitian selanjutnya merupakan cerminan penelitian sebagai proses 'permainan tanpa henti' dalam rangka memahami beragam fenomena. Kemampuan mengidentifikasi penelitian selanjutnya menunjukkan suasana kebatinan proses penelitian yang menemukan banyak sekali pertanyaan dan fakta baru yang tidak mungkin dijawab karena keterbatasan sumberdaya. 
Tabel 4 Sebaran artikel berdasarkan penulis, tahun terbit, tujuan, hasil, limitasi, dan agenda penelitian selanjutnya

\begin{tabular}{|c|c|c|c|c|c|c|c|}
\hline No. & Penulis & $\begin{array}{l}\text { Tahun } \\
\text { terbit }\end{array}$ & Tujuan penelitian & Hasil penelitian & Koding & $\begin{array}{l}\text { Limitasi } \\
\text { penelitian }\end{array}$ & $\begin{array}{l}\text { Agenda riset } \\
\text { selanjutnya }\end{array}$ \\
\hline 1 & Abdurrazaq & 2013 & $\begin{array}{l}\text { Menganalisis pesan } \\
\text { dakwah dalam novel } \\
\text { Islami karya } \\
\text { Habiburrahman El- } \\
\text { Shirazi. }\end{array}$ & $\begin{array}{l}\text { Habiburrahman El Shirazi } \\
\text { mampu menggunakan novel } \\
\text { sebagai media dakwah }\end{array}$ & $\begin{array}{l}\text { Pesan } \\
\text { dakwah }\end{array}$ & $\begin{array}{l}\text { Informasi } \\
\text { tidak } \\
\text { tersedia }\end{array}$ & $\begin{array}{l}\text { Informasi } \\
\text { tidak tersedia }\end{array}$ \\
\hline 2 & Arsam & 2014 & $\begin{array}{l}\text { Mendeskripsikan pola } \\
\text { monitoring dan evaluasi } \\
\text { kegiatan dakwah di } \\
\text { Masjid ash-Shiddiq, } \\
\text { Semarang. }\end{array}$ & $\begin{array}{l}\text { Monev dilakukan dengan } \\
\text { kunjungan lapangan, pembuatan } \\
\text { laporan, kesesuaian perencanaan } \\
\text { dakwah dengan kebutuhan umat }\end{array}$ & $\begin{array}{l}\text { Manajemen } \\
\text { dakwah }\end{array}$ & $\begin{array}{l}\text { Informasi } \\
\text { tidak } \\
\text { tersedia }\end{array}$ & $\begin{array}{l}\text { Informasi } \\
\text { tidak tersedia }\end{array}$ \\
\hline 3 & Bandarsyah & 2016 & $\begin{array}{l}\text { Mendeskripsikan } \\
\text { dinamika tajdid gerakan } \\
\text { dakwah }\end{array}$ & $\begin{array}{l}\text { Tajidid Muhammadiyah berakar } \\
\text { pada konteks historis dan } \\
\text { dinamika kemodernan. }\end{array}$ & $\begin{array}{l}\text { Organisasi } \\
\text { dakwah }\end{array}$ & $\begin{array}{l}\text { Informasi } \\
\text { tidak } \\
\text { tersedia }\end{array}$ & $\begin{array}{l}\text { Informasi } \\
\text { tidak tersedia }\end{array}$ \\
\hline
\end{tabular}

$418 \mid$ JURNAL LISAN AL-HAL 
"Volume 13, No. 2, Desember 2019"

\begin{tabular}{|c|c|c|c|c|c|c|c|}
\hline & & & Muhammadiyah & & & & \\
\hline 4 & $\begin{array}{l}\text { Bin Sanusi } \\
\& \\
\text { Mohamed }\end{array}$ & 2017 & $\begin{array}{l}\text { Menganalisis relasi } \\
\text { nasyid dengan dakwah }\end{array}$ & $\begin{array}{l}\text { Dakwah dengan nasyid tidak } \\
\text { melanggar syari'at Islam }\end{array}$ & $\begin{array}{l}\text { Pesan } \\
\text { dakwah }\end{array}$ & $\begin{array}{l}\text { Informasi } \\
\text { tidak } \\
\text { tersedia }\end{array}$ & $\begin{array}{l}\text { Informasi } \\
\text { tidak tersedia }\end{array}$ \\
\hline 5 & Bukhari & 2015 & $\begin{array}{l}\text { Menganalisis relasi da'i } \\
\text { dan mad'u dalam } \\
\text { komunitas Jemaah } \\
\text { Tabligh di Kota Padang, } \\
\text { Sumatera Barat }\end{array}$ & $\begin{array}{l}\text { Dakwah jamaah Tabligh diterima } \\
\text { warga karena aspek keyakinan, } \\
\text { persuasif, bahasa yang menarik } \\
\text { dan tidak mempersoalkan } \\
\text { khilafiyah. Ada juga warga yang } \\
\text { menolak karena dianggap } \\
\text { fatalistis, tidak mementingkan } \\
\text { duniawi dan perilaku yang } \\
\text { kurang simpatik. }\end{array}$ & $\begin{array}{l}\text { Praktik } \\
\text { dakwah }\end{array}$ & $\begin{array}{l}\text { Penelitian } \\
\text { hanya } \\
\text { terbatas } \\
\text { pada } \\
\text { interaksi } \\
\text { simbolik } \\
\text { da'i dan } \\
\text { mad'u } \\
\text { Jamaah } \\
\text { Tabligh di } \\
\text { Kota } \\
\text { Padang }\end{array}$ & $\begin{array}{l}\text { Aspek } \\
\text { teologis, fikh, } \\
\text { dan } \\
\text { pengamalan } \\
\text { agama para } \\
\text { anggota } \\
\text { Jamaah } \\
\text { Tabligh. }\end{array}$ \\
\hline 6 & Choiriyah & 2013 & $\begin{array}{l}\text { Menganalisis materi } \\
\text { dakwah dalam lirik lagu } \\
\text { Izinkan Aku Reguk }\end{array}$ & $\begin{array}{l}\text { Lagu Izinkan Aku Reguk Cinta-Mu } \\
\text { mengandung materi dakwah } \\
\text { tentang aqidah (tauhid }\end{array}$ & $\begin{array}{l}\text { Pesan } \\
\text { dakwah }\end{array}$ & $\begin{array}{l}\text { Informasi } \\
\text { tidak } \\
\text { tersedia }\end{array}$ & $\begin{array}{l}\text { Informasi } \\
\text { tidak tersedia }\end{array}$ \\
\hline
\end{tabular}




\begin{tabular}{|c|c|c|c|c|c|c|c|}
\hline & & & $\begin{array}{l}\text { Cinta-Mu karya Ebiet G. } \\
\text { Ade. }\end{array}$ & $\begin{array}{l}\text { rububiyah), cinta dan takut } \\
\text { kepada azab Allah SWT, dan } \\
\text { ibadah. }\end{array}$ & & & \\
\hline 7 & Dalmeri & 2014 & $\begin{array}{l}\text { Menganalisis fungsi } \\
\text { masjid sebagai pusat } \\
\text { kegiatan ibadah dan } \\
\text { aktivitas sosial-ekonomi } \\
\text { umat Islam. }\end{array}$ & $\begin{array}{l}\text { Masjid dapat difungsikan sebagai } \\
\text { tempat pemberdayaan umat } \\
\text { Islam melalui peningkatan } \\
\text { pengetahuan, kesadaran, } \\
\text { keterampilan, pendampingan, } \\
\text { dan memobilisasi sumber } \\
\text { produktif untuk kegiatan } \\
\text { ekonomi dan dakwah. }\end{array}$ & $\begin{array}{l}\text { Manajemen } \\
\text { dakwah }\end{array}$ & $\begin{array}{l}\text { Informasi } \\
\text { tidak } \\
\text { tersedia }\end{array}$ & $\begin{array}{l}\text { Informasi } \\
\text { tidak tersedia }\end{array}$ \\
\hline 8 & $\begin{array}{l}\text { Dwiningru } \\
\mathrm{m}\end{array}$ & 2014 & $\begin{array}{l}\text { Menganalisis pola } \\
\text { dakwah multikultural di } \\
\text { sekolah menengah } \\
\text { umum }\end{array}$ & $\begin{array}{l}\text { Dakwah multikultural di sekolah } \\
\text { merupakan kombinasi } \\
\text { pendekatan kontribusi, aditif, } \\
\text { transformasi, dan aksi sosial. } \\
\text { Dakwah multikultural membantu } \\
\text { siswa mengembangkan identitas } \\
\text { sosial berdasarkan nilai-nilai } \\
\text { keadilan, kesetaraan dan } \\
\text { menghargai perbedaan. }\end{array}$ & $\begin{array}{l}\text { Manajemen } \\
\text { dakwah }\end{array}$ & $\begin{array}{l}\text { Informasi } \\
\text { tidak } \\
\text { tersedia }\end{array}$ & $\begin{array}{l}\text { Informasi } \\
\text { tidak tersedia }\end{array}$ \\
\hline
\end{tabular}

$420 \mid$ JURNAL LISAN AL-HAL 


\begin{tabular}{|c|c|c|c|c|c|c|c|}
\hline 9 & $\begin{array}{l}\text { Fatmawati } \\
\text { \& Diania }\end{array}$ & 2016 & $\begin{array}{l}\text { Menganalisis dakwah } \\
\text { Gafatar dalam } \\
\text { perspektif shifting } \\
\text { paradigm }\end{array}$ & $\begin{array}{l}\text { Gafatar, yang mengedepankan } \\
\text { kegiatan sosial sebagai ciri khas } \\
\text { dakwah, telah merubah ideologi } \\
\text { gerakannya karena anomali } \\
\text { berupa perlawanan dari ormas } \\
\text { dan pemerintah. }\end{array}$ & $\begin{array}{l}\text { Organisasi } \\
\text { dakwah }\end{array}$ & $\begin{array}{l}\text { Informasi } \\
\text { tidak } \\
\text { tersedia }\end{array}$ & $\begin{array}{l}\text { Informasi } \\
\text { tidak tersedia }\end{array}$ \\
\hline 10 & Haryanto & 2016 & $\begin{array}{l}\text { Menganalisis pesan } \\
\text { dakwah dalam buletin } \\
\text { Jum'at Himmah yang } \\
\text { dikelola masjid kampus } \\
\text { IAIN Palangkaraya. }\end{array}$ & $\begin{array}{l}\text { Pesan dakwah buletin Jum'at } \\
\text { Himmah IAIN Palangkaraya } \\
\text { mengandung materi aqidah, } \\
\text { syari'ah, dan akhlah. }\end{array}$ & $\begin{array}{l}\text { Pesan } \\
\text { dakwah }\end{array}$ & $\begin{array}{l}\text { Informasi } \\
\text { tidak } \\
\text { tersedia }\end{array}$ & $\begin{array}{l}\text { Informasi } \\
\text { tidak tersedia }\end{array}$ \\
\hline 11 & Hayat & 2014 & $\begin{array}{l}\text { Menganalisis pengajian } \\
\text { Yasinan sebagai strategi } \\
\text { dakwah NU. }\end{array}$ & $\begin{array}{l}\text { Yasinan merupakan local wisdom } \\
\text { yang sampai hari ini masih efektif } \\
\text { dalam menyampaikan ayat-ayat } \\
\text { al-Qur'an dan Hadits untuk } \\
\text { penguatan keimanan dan } \\
\text { ketakwaan. }\end{array}$ & $\begin{array}{l}\text { Praktik } \\
\text { dakwah }\end{array}$ & $\begin{array}{l}\text { Informasi } \\
\text { tidak } \\
\text { tersedia }\end{array}$ & $\begin{array}{l}\text { Informasi } \\
\text { tidak tersedia }\end{array}$ \\
\hline 12 & Hidayanti & 2014 & $\begin{array}{l}\text { Mendeskripsikan } \\
\text { aktivitas dakwah pada }\end{array}$ & $\begin{array}{l}\text { Pelayanan bimbingan Islam lebih } \\
\text { dominan daripada pelayanan }\end{array}$ & $\begin{array}{l}\text { Praktik } \\
\text { dakwah }\end{array}$ & $\begin{array}{l}\text { Informasi } \\
\text { tidak }\end{array}$ & $\begin{array}{l}\text { Informasi } \\
\text { tidak tersedia }\end{array}$ \\
\hline
\end{tabular}




\begin{tabular}{|c|c|c|c|c|c|c|c|}
\hline & & & $\begin{array}{l}\text { sistem layanan } \\
\text { bimbingan konseling } \\
\text { Islam di rumah sakit }\end{array}$ & konseling. & & tersedia & \\
\hline 13 & $\begin{array}{l}\text { Hun \& Abu } \\
\text { Hasan }\end{array}$ & 2017 & $\begin{array}{l}\text { Menganalisis } \\
\text { penggabungan tema } \\
\text { Islam dengan hasrat } \\
\text { cinta kasih dalam Ayat- } \\
\text { Ayat Cinta } 2 \text {. }\end{array}$ & $\begin{array}{l}\text { Hasrat cinta kasih harus } \\
\text { didasarkan kepada rasa cinta } \\
\text { kepada Allah SWT. }\end{array}$ & $\begin{array}{l}\text { Pesan } \\
\text { dakwah }\end{array}$ & $\begin{array}{l}\text { Informasi } \\
\text { tidak } \\
\text { tersedia }\end{array}$ & $\begin{array}{l}\text { Informasi } \\
\text { tidak tersedia }\end{array}$ \\
\hline 14 & Isnania & 2013 & $\begin{array}{l}\text { Mendeskripsikan } \\
\text { bentuk dan makna } \\
\text { jargon dakwah yang } \\
\text { digunakan aktivis } \\
\text { dakwah kampus di Kota } \\
\text { Surakarta dan } \\
\text { kontribusinya terhadap } \\
\text { dakwah Islam. }\end{array}$ & $\begin{array}{l}\text { Jargon dakwah aktivis dakwah } \\
\text { kampus di Kota Surakarta } \\
\text { kebanyakan berasal dari bahasa } \\
\text { Arab dan tidak berupa kalimat. } \\
\text { Penggunaan jargon tersebut tidak } \\
\text { dibedakan berdasarkan status } \\
\text { sosial, letak geografis, dan tingkat } \\
\text { pendidikan. Makna jargon } \\
\text { dakwah tidak hanya leksikal, } \\
\text { tetapi juga kontekstual. }\end{array}$ & $\begin{array}{l}\text { Pesan } \\
\text { dakwah }\end{array}$ & $\begin{array}{l}\text { Informasi } \\
\text { tidak } \\
\text { tersedia }\end{array}$ & $\begin{array}{l}\text { Informasi } \\
\text { tidak tersedia }\end{array}$ \\
\hline 15 & Jalil & 2014 & Menganalisis perilaku & Perilaku kekerasan ini & Praktik & Informasi & Informasi \\
\hline
\end{tabular}

$422 \mid$ JURNAL LISAN AL-HAL 
"Telaah Literatur Dakwah Di Indonesia "

\begin{tabular}{|c|c|c|c|c|c|c|c|}
\hline & & & & aspek politik lebih diuntungkan. & & & \\
\hline 18 & Latief & 2012 & $\begin{array}{l}\text { Menganalisis peran } \\
\text { organisasi filantropi } \\
\text { Islam di Kabupaten Nias }\end{array}$ & $\begin{array}{l}\text { Di Kabupaten Nias, yang } \\
\text { penduduknya mayoritas non- } \\
\text { muslim, mayoritas dakwah bil hal } \\
\text { lembaga filantropi difokuskan } \\
\text { untuk mendirikan lembaga } \\
\text { pendidikan. Penerima manfaat } \\
\text { program juga ada yang non- } \\
\text { muslim. }\end{array}$ & $\begin{array}{l}\text { Organisasi } \\
\text { dakwah }\end{array}$ & $\begin{array}{l}\text { Informasi } \\
\text { tidak } \\
\text { tersedia }\end{array}$ & $\begin{array}{l}\text { Informasi } \\
\text { tidak tersedia }\end{array}$ \\
\hline 19 & Ma'arif & 2011 & $\begin{array}{l}\text { Menganalisis } \\
\text { inklusivitas pesan } \\
\text { dakwah KH. Abdullah } \\
\text { Gymnastiar dan KH. } \\
\text { Jalaludin Rahmat }\end{array}$ & $\begin{array}{l}\text { Inti pesan dakwah kedua da'i } \\
\text { adalah pesan-pesan inklusif yang } \\
\text { mengutamakan kesetaraan } \\
\text { manusia, etika, toleransi, dan } \\
\text { relasi resiprokal yang setara. } \\
\text { Pesan inklusif semacam ini ideal } \\
\text { bagi Indonesia yang sangat } \\
\text { multikultural }\end{array}$ & $\begin{array}{l}\text { Pesan } \\
\text { dakwah }\end{array}$ & $\begin{array}{l}\text { Informasi } \\
\text { tidak } \\
\text { tersedia }\end{array}$ & $\begin{array}{l}\text { Informasi } \\
\text { tidak tersedia }\end{array}$ \\
\hline 20 & Ma'arif & 2009 & $\begin{array}{l}\text { Menganalisis gaya } \\
\text { retorika dua da'i (KH. }\end{array}$ & $\begin{array}{l}\text { Retorika KH. Abdullah } \\
\text { Gymnastiar bersifat friendly dan }\end{array}$ & $\begin{array}{l}\text { Pesan } \\
\text { dakwah }\end{array}$ & $\begin{array}{l}\text { Informasi } \\
\text { tidak }\end{array}$ & $\begin{array}{l}\text { Informasi } \\
\text { tidak tersedia }\end{array}$ \\
\hline
\end{tabular}

$424 \mid$ JURNAL LISAN AL-HAL 


\begin{tabular}{|c|c|c|c|c|c|c|c|}
\hline & & & $\begin{array}{l}\text { Abdullah Gymnastiar } \\
\text { dan KH. Jalaludin } \\
\text { Rahmat) dan } \\
\text { determinan komunikasi } \\
\text { dakwah. }\end{array}$ & $\begin{array}{l}\text { dramatic, sedangkan retoritas } \\
\text { KH. Jalaludin Rahmat bersifat } \\
\text { contentious dan open. Sejarah } \\
\text { hidup, kapasitas personal, dan } \\
\text { pengalaman beragama } \\
\text { merupakan determinan gaya } \\
\text { retoritka mereka. }\end{array}$ & & tersedia & \\
\hline 21 & Masmuddin & 2014 & $\begin{array}{l}\text { Menganalisis } \\
\text { komunikasi antar umat } \\
\text { beragama di Kota } \\
\text { Palopo }\end{array}$ & $\begin{array}{l}\text { Bentuk-bentuk komunikasi antar } \\
\text { umat beragama di Kota Palopo bil } \\
\text { lisan dan bil hal. }\end{array}$ & $\begin{array}{l}\text { Praktik } \\
\text { dakwah }\end{array}$ & $\begin{array}{l}\text { Informasi } \\
\text { tidak } \\
\text { tersedia }\end{array}$ & $\begin{array}{l}\text { Informasi } \\
\text { tidak tersedi }\end{array}$ \\
\hline 22 & Najitama & 2016 & $\begin{array}{l}\text { Menganalisis identitas } \\
\text { sosial komunitas } \\
\text { Padepokan Dakwah } \\
\text { Sunan Kalijaga } \\
\text { (Padasuka). }\end{array}$ & $\begin{array}{l}\text { Kiai Syarif, elite Padasuka, } \\
\text { mempunyai posisi dominan } \\
\text { dalam proses reproduksi } \\
\text { identitas karena memiliki modal } \\
\text { sosial dan kultural yang kuat. Di } \\
\text { Padasuka, identitas budaya } \\
\text { bukan hanya menentukan kode } \\
\text { etik, namun menjadi alat } \\
\text { resistensi atas dominasi budaya }\end{array}$ & $\begin{array}{l}\text { Organisasi } \\
\text { dakwah }\end{array}$ & $\begin{array}{l}\text { Informasi } \\
\text { tidak } \\
\text { tersedia }\end{array}$ & $\begin{array}{l}\text { Informasi } \\
\text { tidak tersedi }\end{array}$ \\
\hline
\end{tabular}


"Telaah Literatur Dakwah Di Indonesia "

\begin{tabular}{|c|c|c|c|c|c|c|c|}
\hline & & & & luar. & & & \\
\hline 23 & Nasrullah & 2016 & $\begin{array}{l}\text { Menelusuri nilai-nilai } \\
\text { yang terkandung dalam } \\
\text { meme sebagai artefak } \\
\text { budaya. }\end{array}$ & $\begin{array}{l}\text { Meme mengandung nilai-nilai } \\
\text { budaya dan nilai-nilai keislaman } \\
\text { yang dipertukarkan dan } \\
\text { dikembangkan antar pengguna } \\
\text { media sosial. }\end{array}$ & $\begin{array}{l}\text { Pesan } \\
\text { dakwah }\end{array}$ & $\begin{array}{l}\text { Informasi } \\
\text { tidak } \\
\text { tersedia }\end{array}$ & $\begin{array}{l}\text { Informasi } \\
\text { tidak tersedia }\end{array}$ \\
\hline 24 & Novaili & 2016 & $\begin{array}{l}\text { Menganalisis } \\
\text { signifikansi metode } \\
\text { dakwah penyuluh } \\
\text { agama Islam di Kantor } \\
\text { Urusan Agama (KUA) } \\
\text { dalam penyuluhan } \\
\text { pasangan calon suami } \\
\text { istri. }\end{array}$ & $\begin{array}{l}\text { Peran penyuluh agama Islam } \\
\text { cukup signifikan karena memberi } \\
\text { modal pengetahuan dan } \\
\text { mental/kesadaran kepada calon } \\
\text { pengantin. }\end{array}$ & $\begin{array}{l}\text { Manajemen } \\
\text { dakwah }\end{array}$ & $\begin{array}{l}\text { Informasi } \\
\text { tidak } \\
\text { tersedia }\end{array}$ & $\begin{array}{l}\text { Informasi } \\
\text { tidak tersedia }\end{array}$ \\
\hline 25 & Nur'aini & 2013 & $\begin{array}{l}\text { Menganalisis corak } \\
\text { pemikiran keagamaan } \\
\text { aktivis Aisyiyah di awal } \\
\text { berdirinya organisasi. }\end{array}$ & $\begin{array}{l}\text { Perlawanan terhadap } \\
\text { kolonialisme membangkitkan } \\
\text { semangat kaum perempuan } \\
\text { menggerakkan kaum muslimat. } \\
\text { Pemikiran para tokoh Aisyiyah }\end{array}$ & $\begin{array}{l}\text { Organisasi } \\
\text { dakwah }\end{array}$ & $\begin{array}{l}\text { Informasi } \\
\text { tidak } \\
\text { tersedia }\end{array}$ & $\begin{array}{l}\text { Informasi } \\
\text { tidak tersedia }\end{array}$ \\
\hline
\end{tabular}

$426 \mid$ JURNAL LISAN AL-HAL 
"Volume 13, No. 2, Desember 2019"

\begin{tabular}{|c|c|c|c|c|c|c|c|}
\hline & & & & $\begin{array}{l}\text { termasuk paham modernisme } \\
\text { Islam. Mereka menyadari } \\
\text { pentingnya partisipasi } \\
\text { perempuan dalam Dakwah Islam } \\
\text { untuk mempercepat terwujudnya } \\
\text { masyarakat sejahtera. }\end{array}$ & & & \\
\hline 26 & Pahlevi & 2016 & $\begin{array}{l}\text { Menganalisis aktivitas } \\
\text { dakwah kultural melalui } \\
\text { Bayt al-Qur'an al-Akbar } \\
\text { ukiran khas Melayu } \\
\text { Palembang. }\end{array}$ & $\begin{array}{l}\text { Bayt al-Qur'an al-Akbar ukiran } \\
\text { khas Melayu Palembang } \\
\text { merupakan dakwah kultural } \\
\text { melalui seni dan memicu lahirnya } \\
\text { destinasi wisata religi di Kota } \\
\text { Palembang. }\end{array}$ & $\begin{array}{l}\text { Praktik } \\
\text { dakwah }\end{array}$ & $\begin{array}{l}\text { Informasi } \\
\text { tidak } \\
\text { tersedia }\end{array}$ & $\begin{array}{l}\text { Informasi } \\
\text { tidak tersedia }\end{array}$ \\
\hline 27 & $\begin{array}{l}\text { Rachmiatie, } \\
\text { Sidik, \& } \\
\text { Farihat }\end{array}$ & 2004 & $\begin{array}{l}\text { Menganalisis proses } \\
\text { sosialisasi agama Islam } \\
\text { yang disampaikan } \\
\text { melalui media } \\
\text { komunitas (elektronik } \\
\text { dan cetak) untuk remaja } \\
\text { muslim. }\end{array}$ & $\begin{array}{l}\text { Responden memandang positif } \\
\text { proses sosialisasi informasi } \\
\text { agama Islam melalui media } \\
\text { komunitas. }\end{array}$ & $\begin{array}{l}\text { Pesan } \\
\text { dakwah }\end{array}$ & $\begin{array}{l}\text { Informasi } \\
\text { tidak } \\
\text { tersedia }\end{array}$ & $\begin{array}{l}\text { Informasi } \\
\text { tidak tersedia }\end{array}$ \\
\hline
\end{tabular}




\begin{tabular}{|c|c|c|c|c|c|c|c|}
\hline 28 & Raihan & 2015 & $\begin{array}{l}\text { Menganalisis kinerja } \\
\text { Dewah Dakwah } \\
\text { Islamiyah Indonesia } \\
\text { (DDII) }\end{array}$ & $\begin{array}{l}\text { DDII Provinsi Aceh kurang } \\
\text { produktif karena minimnya } \\
\text { partisipasi pengurus dalam } \\
\text { kegiatan dakwah. DDII Aceh } \\
\text { kekurangan dana sehingga } \\
\text { sebagian pleksanaan program } \\
\text { dakwah tertunda atau gagal. }\end{array}$ & $\begin{array}{l}\text { Organisasi } \\
\text { dakwah }\end{array}$ & $\begin{array}{l}\text { Informasi } \\
\text { tidak } \\
\text { tersedia }\end{array}$ & $\begin{array}{l}\text { Informasi } \\
\text { tidak tersedia }\end{array}$ \\
\hline 29 & Razzaq & 2014 & $\begin{array}{l}\text { Menganalisis program } \\
\text { filantropi perbankan } \\
\text { syariah }\end{array}$ & $\begin{array}{l}\text { Program filantropi berbentuk } \\
\text { corporate social responsibility } \\
\text { (CSR) yang dijalankan Perbankan } \\
\text { Syariah di Indonesia telah } \\
\text { menyentuh aspek-aspek penting } \\
\text { pembangunan umat, yaitu: } \\
\text { kesehatan, pendidikan dan } \\
\text { kesejahteraan. }\end{array}$ & $\begin{array}{l}\text { Praktik } \\
\text { dakwah }\end{array}$ & $\begin{array}{l}\text { Informasi } \\
\text { tidak } \\
\text { tersedia }\end{array}$ & $\begin{array}{l}\text { Informasi } \\
\text { tidak tersedia }\end{array}$ \\
\hline 30 & Riyadi & 2014 & $\begin{array}{l}\text { Menganalisis model } \\
\text { dakwah melalui sistem } \\
\text { layanan bimbingan } \\
\text { rohani Islam di rumah }\end{array}$ & $\begin{array}{l}\text { Pasien tidak hanya } \\
\text { membutuhkan terapi medis, } \\
\text { tetapi juga terapi keagamaan. } \\
\text { Terapi keagamaan bukan sekedar } \\
\text { pemberian layanan doa, nasehat, }\end{array}$ & $\begin{array}{l}\text { Praktik } \\
\text { dakwah }\end{array}$ & $\begin{array}{l}\text { Informasi } \\
\text { tidak } \\
\text { tersedia }\end{array}$ & $\begin{array}{l}\text { Informasi } \\
\text { tidak tersedia }\end{array}$ \\
\hline
\end{tabular}

$428 \mid$ JURNAL LISAN AL-HAL 
"Volume 13, No. 2, Desember 2019"

\begin{tabular}{|c|c|c|c|c|c|c|c|}
\hline & & & sakit & $\begin{array}{l}\text { atau bimbingan ibadah saja, } \\
\text { tetapi juga disertai layanan } \\
\text { konseling untuk membantu } \\
\text { pasien menemukan dan } \\
\text { melepaskan diri dari core } \\
\text { problem yang dialaminya. }\end{array}$ & & & \\
\hline 31 & Rosa & 2014 & $\begin{array}{l}\text { Menganalisis kegiatan } \\
\text { Majelis Dzikir Susilo } \\
\text { Bambang Yudhoyono } \\
\text { (SBY) "Nurussalam". }\end{array}$ & $\begin{array}{l}\text { Majlis ini menjadikan ayat al- } \\
\text { Qur'an yang berkaitan dengan } \\
\text { konsep al-ummah, al-ukhuwwah } \\
\text { al-islāmiyyah, dan al-ta'āwun } \\
\text { sebagai landasan muatan dakwah } \\
\text { mereka. } \\
\text { Aktivitas dakwah mereka tidak } \\
\text { bisa menghindar dari } \\
\text { kepentingan politik SBY. }\end{array}$ & $\begin{array}{l}\text { Praktik } \\
\text { dakwah }\end{array}$ & $\begin{array}{l}\text { Informasi } \\
\text { tidak } \\
\text { tersedia }\end{array}$ & $\begin{array}{l}\text { Informasi } \\
\text { tidak tersedia }\end{array}$ \\
\hline 32 & Saifullah & 2014 & $\begin{array}{l}\text { Menganalisis praktik } \\
\text { Pesantren Ngalah dalam } \\
\text { dakwah multikultural }\end{array}$ & $\begin{array}{l}\text { Strategi pendidikan multikultural } \\
\text { yang dipraktekkan Pesantren } \\
\text { Ngalah merupakan solusi } \\
\text { alternatif untuk meredam }\end{array}$ & $\begin{array}{l}\text { Praktik } \\
\text { dakwah }\end{array}$ & $\begin{array}{l}\text { Informasi } \\
\text { tidak } \\
\text { tersedia }\end{array}$ & $\begin{array}{l}\text { Informasi } \\
\text { tidak tersedia }\end{array}$ \\
\hline
\end{tabular}


"Telaah Literatur Dakwah Di Indonesia "

\begin{tabular}{|c|c|c|c|c|c|c|c|}
\hline & & & & radikalisme agama & & & \\
\hline 33 & Shobron & 2014 & $\begin{array}{l}\text { Menganalisis model } \\
\text { dakwah Hizbut Tahrir } \\
\text { Indonesia (HTI) }\end{array}$ & $\begin{array}{l}\text { HTI berdakwah secara kultural } \\
\text { dan struktural. Tetapi, dakwah } \\
\text { struktural masih berkisar } \\
\text { pembentukan opini publik. } \\
\text { Mereka belum berani tampil } \\
\text { menjadi partai politik yang resmi } \\
\text { diakui pemerintah. }\end{array}$ & $\begin{array}{l}\text { Organisasi } \\
\text { dakwah }\end{array}$ & $\begin{array}{l}\text { Informasi } \\
\text { tidak } \\
\text { tersedia }\end{array}$ & $\begin{array}{l}\text { Informasi } \\
\text { tidak tersedia }\end{array}$ \\
\hline 34 & $\begin{array}{l}\text { Shobron, } \\
\text { Rosyadi, \& } \\
\text { Suaidy }\end{array}$ & 2015 & $\begin{array}{l}\text { Menganalisis } \\
\text { implementasi peran } \\
\text { dakwah bil-hâl Pondok } \\
\text { Pesanten Wali Songo } \\
\text { dalam pemberdayaan } \\
\text { ekonomi masyarakat. }\end{array}$ & $\begin{array}{l}\text { Pondok Pesantren Wali Songo } \\
\text { Ngabar mensinergikan dakwah } \\
\text { bil-lisân dan dakwah bil-hâl. } \\
\text { Program dakwah bil-hâl mereka } \\
\text { cukup berhasil. }\end{array}$ & $\begin{array}{l}\text { Praktik } \\
\text { dakwah }\end{array}$ & $\begin{array}{l}\text { Informasi } \\
\text { tidak } \\
\text { tersedia }\end{array}$ & $\begin{array}{l}\text { Informasi } \\
\text { tidak tersedia }\end{array}$ \\
\hline 35 & Shodiq & 2015 & $\begin{array}{l}\text { Menganalisis } \\
\text { perkembangan } \\
\text { komunitas Tarekat } \\
\text { Shiddiqiyah di Kota } \\
\text { Surabaya. }\end{array}$ & $\begin{array}{l}\text { Tarekat Shiddiqiyah berkembang } \\
\text { secara evolutif. Mereka juga } \\
\text { melembagakan aktivitas mereka } \\
\text { ke dalam organisasi formal (YPS } \\
\text { dan Orshid). Motif seseorang }\end{array}$ & $\begin{array}{l}\text { Organisasi } \\
\text { dakwah }\end{array}$ & $\begin{array}{l}\text { Informasi } \\
\text { tidak } \\
\text { tersedia }\end{array}$ & $\begin{array}{l}\text { Informasi } \\
\text { tidak tersedia }\end{array}$ \\
\hline
\end{tabular}

$430 \mid$ JURNAL LISAN AL-HAL 
"Volume 13, No. 2, Desember 2019"

\begin{tabular}{|c|c|c|c|c|c|c|c|}
\hline & & & & $\begin{array}{l}\text { bergabung ke komunitas ini } \\
\text { adalah meningkatkan } \\
\text { pengetahuan agama, zikir dan } \\
\text { wirid, dan tolak balak. Relasi } \\
\text { mereka dengan warga } \\
\text { masyarakat harmonis karena } \\
\text { mereka mampu beradaptasi dan } \\
\text { berasimilasi dengan budaya lokal. }\end{array}$ & & & \\
\hline 36 & Sofjan & 2012 & $\begin{array}{l}\text { Menganalisis kontruksi } \\
\text { gender dalam tayangan } \\
\text { Dakwahtainment }\end{array}$ & $\begin{array}{l}\text { Program Hati ke Hati Bersama } \\
\text { Mamah Dedeh dikonstruk } \\
\text { berdasarkan pemahaman relasi } \\
\text { gender yang rancu dan saling } \\
\text { bertentangan. Program ini dapat } \\
\text { memberdayakan dan/atau } \\
\text { memperdaya pemirsa } \\
\text { perempuan. }\end{array}$ & $\begin{array}{l}\text { Pesan } \\
\text { dakwah }\end{array}$ & $\begin{array}{l}\text { Informasi } \\
\text { tidak } \\
\text { tersedia }\end{array}$ & $\begin{array}{l}\text { Informasi } \\
\text { tidak tersedia }\end{array}$ \\
\hline 37 & Sukardi & 2014 & $\begin{array}{l}\text { Menganalisis dakwah bil } \\
\text { lisan dengan teknik } \\
\text { hiburan di Kota Banda } \\
\text { Aceh }\end{array}$ & $\begin{array}{l}\text { Materi dakwah bi al-lisān dengan } \\
\text { teknik hiburan di Kota Banda } \\
\text { Aceh mudah dipahami. } \\
\text { Masyarakat menyambut positif }\end{array}$ & $\begin{array}{l}\text { Praktik } \\
\text { dakwah }\end{array}$ & $\begin{array}{l}\text { Informasi } \\
\text { tidak } \\
\text { tersedia }\end{array}$ & $\begin{array}{l}\text { Informasi } \\
\text { tidak tersedia }\end{array}$ \\
\hline
\end{tabular}


"Telaah Literatur Dakwah Di Indonesia "

\begin{tabular}{|c|c|c|c|c|c|c|c|}
\hline & & & & $\begin{array}{l}\text { content humor dalam dakwah } \\
\text { karena memotivasi para audiens } \\
\text { mendengarkan dakwah. Tetapi, } \\
\text { humor bisa berdampak negatif } \\
\text { ketika banyak tertawa menutupi } \\
\text { hati dan subtansi dakwah. }\end{array}$ & & & \\
\hline 38 & Sunarwoto & 2014 & $\begin{array}{l}\text { Mendiskusikan program } \\
\text { tanya jawab di radio } \\
\text { dakwah }\end{array}$ & $\begin{array}{l}\text { Tanya jawab merupakan bagian } \\
\text { dari fatwa }\end{array}$ & $\begin{array}{l}\text { Praktik } \\
\text { dakwah }\end{array}$ & $\begin{array}{l}\text { Informasi } \\
\text { tidak } \\
\text { tersedia }\end{array}$ & $\begin{array}{l}\text { Informasi } \\
\text { tidak tersedia }\end{array}$ \\
\hline 39 & Susanto & 2013 & $\begin{array}{l}\text { Menjelaskan praktik } \\
\text { dakwah dengan } \\
\text { psikoterapi religius }\end{array}$ & $\begin{array}{l}\text { Terapi religius Pondok Pesantren } \\
\text { Istighfar lebih menekankan } \\
\text { model psikoterapi illahiah yang } \\
\text { didasarkan pada nilai-nilai } \\
\text { spiritualitas dalam bentuk amal- } \\
\text { amal ibadah untuk mendapatkan } \\
\text { hidayah dari yang Maha Kuasa. }\end{array}$ & $\begin{array}{l}\text { Praktik } \\
\text { dakwah }\end{array}$ & $\begin{array}{l}\text { Informasi } \\
\text { tidak } \\
\text { tersedia }\end{array}$ & $\begin{array}{l}\text { Informasi } \\
\text { tidak tersedia }\end{array}$ \\
\hline 40 & Susanto & 2014 & $\begin{array}{l}\text { Menganalisis ruqyah } \\
\text { sebagai metode dakwah }\end{array}$ & $\begin{array}{l}\text { Ruqyah merupakan bagian dari } \\
\text { dakwah karena menggunakan } \\
\text { ayat-ayat al-Quran sebagai terapi }\end{array}$ & $\begin{array}{l}\text { Praktik } \\
\text { dakwah }\end{array}$ & $\begin{array}{l}\text { Informasi } \\
\text { tidak } \\
\text { tersedia }\end{array}$ & $\begin{array}{l}\text { Informasi } \\
\text { tidak tersedia }\end{array}$ \\
\hline
\end{tabular}

432 JURNAL LISAN AL-HAL 
"Volume 13, No. 2, Desember 2019"

\begin{tabular}{|c|c|c|c|c|c|c|c|}
\hline & & & & pengobatan & & & \\
\hline 41 & Syobah & 2015 & $\begin{array}{l}\text { Menganalisis efektivitas } \\
\text { program dakwah TVRI } \\
\text { Kaltim }\end{array}$ & $\begin{array}{l}\text { Dakwah di TVRI Kalimantan } \\
\text { Timur belum efektif. Masih } \\
\text { banyak kekurangan yang harus } \\
\text { segera dibenahi dan ditingkatkan. }\end{array}$ & $\begin{array}{l}\text { Praktik } \\
\text { dakwah }\end{array}$ & $\begin{array}{l}\text { Informasi } \\
\text { tidak } \\
\text { tersedia }\end{array}$ & $\begin{array}{l}\text { Informasi } \\
\text { tidak tersedia }\end{array}$ \\
\hline 42 & Ubaidillah & 2015 & $\begin{array}{l}\text { Menemukan tema } \\
\text { mayor dan minor dalam } \\
\text { dakwah Nabi } \\
\text { Muhammad di awal } \\
\text { penyebaran Islam. }\end{array}$ & $\begin{array}{l}\text { Selain dakwah Islam sebagai } \\
\text { tema mayor, tema minor dakwah } \\
\text { Rasulullah SAW meliputi: } \\
\text { berdakwah harus karena Allah, } \\
\text { mendoakan keselamatan hanya } \\
\text { untuk muslim, Nabi Isa bukan } \\
\text { anak Tuhan, seluruh ajaran } \\
\text { agama semitik adalah pengesaan } \\
\text { Allah, agama yang diakui Allah } \\
\text { hanya Islam, dan Islam agama } \\
\text { yang toleran. }\end{array}$ & $\begin{array}{l}\text { Pesan } \\
\text { dakwah }\end{array}$ & $\begin{array}{l}\text { Informasi } \\
\text { tidak } \\
\text { tersedia }\end{array}$ & $\begin{array}{l}\text { Informasi } \\
\text { tidak tersedia }\end{array}$ \\
\hline 43 & $\begin{array}{l}\text { Wahyuning } \\
\text { sih }\end{array}$ & 2013 & $\begin{array}{l}\text { Menganalisis pesan- } \\
\text { pesan dakwah (verbal } \\
\text { dan nonverbal) dalam }\end{array}$ & $\begin{array}{l}\text { Pesan dakwah verbal dan non- } \\
\text { verbal dalam film Ayat-Ayat Cinta } \\
\text { ada yang mengajak (amar ma'ruf) }\end{array}$ & $\begin{array}{l}\text { Pesan } \\
\text { dakwah }\end{array}$ & $\begin{array}{l}\text { Informasi } \\
\text { tidak } \\
\text { tersedia }\end{array}$ & $\begin{array}{l}\text { Informasi } \\
\text { tidak tersedia }\end{array}$ \\
\hline
\end{tabular}


"Telaah Literatur Dakwah Di Indonesia "

\begin{tabular}{|c|c|c|c|c|c|c|c|}
\hline & & & film Ayat-Ayat Cinta. & dan melarang (nahi munkar) & & & \\
\hline 44 & Yusuf & 2016 & $\begin{array}{l}\text { Menganalisis aktivitas } \\
\text { dakwah komunitas } \\
\text { Jemaah Tabligh di } \\
\text { Kabupaten Magetan. }\end{array}$ & $\begin{array}{l}\text { Prinsip ikrâm al-Muslim } \\
\text { merupakan salah satu yang } \\
\text { diprioritas Jemaah Tabligh dalam } \\
\text { berdakwah. Ia adalah landasan } \\
\text { ukhuwwah Islâmîyah. }\end{array}$ & $\begin{array}{l}\text { Praktik } \\
\text { dakwah }\end{array}$ & $\begin{array}{l}\text { Informasi } \\
\text { tidak } \\
\text { tersedia }\end{array}$ & $\begin{array}{l}\text { Informasi } \\
\text { tidak tersedia }\end{array}$ \\
\hline
\end{tabular}

434 JURNAL LISAN AL-HAL 


\section{b. Analisis tematik}

Analisis tematik bertolak dari beberapa pertanyaan, yakni: siapa aktor utama yang menjadi da'i? Siapa kelompok sasaran mereka? Seperti apa sifat pesan yang terkandung dalam aktivitas dakwah mereka? Instrumen dakwah seperti apa yang mereka gunakan? Seperti apa teknologi informasi dan komunikasi yang digunakan dalam aktivitas dakwah mereka. Seperti ditunjukkan Tabel 5, aktor dakwah (da'i) bisa dibedakan menjadi tiga jenis yakni pemerintah, pelaku pasar, dan masyarakat sipil. Mayoritas riset tentang dakwah yang dilakukan para peneliti terkonsentrasi ke aktivitas dakwah yang dilakukan masyarakat sipil. Aktivitas dakwah yang dilakukan institusi pemerintah dan korporasi swasta masih jarang ditelaah. Meskipun beberapa aktivitas dakwah melibatkan banyak aktor yang cukup kompleks, misalnya riset Latief (2012) dan Shobron, Rosyadi, and Suaidy (2015), tetapi belum ada penelitian yang menganalisis fenomena ini dengan perspektif jejaring sosial (Wasserman and Faust 1994).

Kelompok sasaran (mad'u) aktivitas terbagi menjadi dua jenis, yakni: kelompok terbatas (jumlah orang bisa dihitung dengan jelas) dan khalayak umum (jumlah orang tidak bisa dihitung). Aktivitas dakwah yang menggunakan instrumen karya seni (misalnya, novel, lagu, dan film) dan teknologi penyiaran konvensional (misalnya, radio dan televisi) atau media tulisan melibatkan kelompok sasaran khalayak umum karena tidak memerlukan mobilitas fisik untuk menyampaikan pesan dakwah. Sebaliknya, aktivitas dakwah bil lisan dengan instrumen tradisional (misalnya, ceramah, pengajian, dan zikir) atau bil hal cenderung hanya mampu menjangkau kelompok sasaran yang terbatas karena mensyaratkan mobilitas fisik pada da'i dan sumberdaya yang juga terbatas.

Terkait dengan populasi mad'u ini, dari sampel artikel yang ditelaah, belum ada riset dakwah yang memosisikan para pengguna internet sebagai populasi, sampel, atau key informan mereka. Padahal, fakta empiris menunjukkan banyak sekali interaksi umat dengan para ulama terjadi di dunia online. Di Twitter, beberapa ulama, misalnya KH. Mustofa Bisri (@gusmusgusmu), KH. Abdullah Gymnastiar (@aagym), Ustadz Yusuf Mansyur (@Yusuf_Mansyur), Felix Siauw (@felixsiauw),dan Solahudin Wahid (@Gus_Solah) secara aktif memanfaatkan media sosial untuk menopang aktivitas dakwah mereka. Di luar artikel sampel, topik ini sudah dielaborasi beberapa peneliti, misalnya Jinan (2013) dan Muchtar and Ritchey (2014). 
Pengertian karya seni sebagai instrumen dakwah juga perlu diperluas, tidak hanya novel, syair lagu, atau kaligrafi, dan industri busana muslim yang cukup berkembang di Tanah Air. Kehadiran mereka tak bisa dilepaskan dari doktrin menutup aurat yang tercantum dalam al-Quran (Q.S. al-Ahzab [33]: 59; Q.S an-Nur [24]: 31). Menurut kami, industri busana muslim adalah salah satu artefak yang menarik ditelaah karena mempertemukan doktrin 'menutup aurat' dengan institusi pasar, dunia fashion yang inovatif, dan konsumerisme. Di luar artikel sampel yang ditelaah, topik ini baru dikaji beberapa peneliti, misalnya Ahmadi \& Yohana (2007) dan Ratri (2011). Karya seni lainnya, misalnya komik, video pendek, dan animasi flash juga perlu mendapatkan serius dari para peneliti dakwah di Indonesia.

Dari sisi isi dan tujuannya pesannya, mayoritas pesan dakwah bersifat eksklusif dan substansi pesan tidak lari dari perihal aqidah, ibadah, dan akhlak. Hanya Dwiningrum (2014) dan Ma'arif (2011) yang meneliti pesan dakwah para da'i yang bersifat inklusif. Tidak ada artikel yang secara khusus membahas pesan dan/atau aktivitas dakwah dengan istilah 'Islam fundamentalis', 'Islam liberal', 'Islam Nusantara', atau 'Islam moderat'. Beberapa artikel hanya fokus ke penerimaan/penolakan pesan dan efektivitas pesan, tetapi belum ada yang mengelaborasi konsep pesan yang 'membekas pada jiwa' (Q.S An-Nisä [4]: 63). Instrumen dakwah yang digunakan adalah bil lisan, bil hal, dan integratif (kombinasi bil lisan dan bil hal). Kami belum menemukan artikel yang mengkaji secara khusus peran teknologi informasi dan komunikasi (misalnya, TV digital, radio digital, blog, website, media sosial, YouTube, pengajian oneline, khataman online) dalam aktivitas dakwah. Riset Nasrullah (2016) memang menyinggung media sosial, tetapi analisisnya lebih fokus ke bentuk pesan dan belum memberikan perhatian secara khusus kepada teknologi informasi dan komunikasi.

\footnotetext{
$436 \mid$ JURNAL LISAN AL-HAL
} 
“Volume 13, No. 2, Desember 2019"

\section{Tabel 5 Matriks analisis tematik}

\begin{tabular}{|c|c|c|c|c|c|c|c|c|}
\hline \multirow[b]{2}{*}{ No. } & \multirow[b]{2}{*}{ Penulis } & \multicolumn{3}{|l|}{ Aktor (da'i) } & \multirow[b]{2}{*}{ Sifat pesan } & \multirow[b]{2}{*}{ Instrumen } & \multirow{2}{*}{$\begin{array}{l}\text { Teknologi } \\
\text { informasi } \\
\text { dan } \\
\text { komunikasi }\end{array}$} & \multirow[b]{2}{*}{ Kelompok sasaran } \\
\hline & & Pemerintah & Korporasi & $\begin{array}{l}\text { Masyarakat } \\
\text { sipil }\end{array}$ & & & & \\
\hline 1 & Abdurrazaq & & & $\begin{array}{l}\text { Seniman } \\
\text { (penulis novel) }\end{array}$ & Ekslusif & $\begin{array}{l}\text { Karya seni, } \\
\text { khususnya } \\
\text { tulisan } \\
\text { berbentuk } \\
\text { novel }\end{array}$ & $\begin{array}{l}\text { Informasi } \\
\text { tidak tersedia }\end{array}$ & Khalayak umum \\
\hline 2 & Arsam & & & $\begin{array}{l}\text { Organisasi } \\
\text { (takmir dan } \\
\text { jemaah masjid) }\end{array}$ & Ekslusif & Lisan & $\begin{array}{l}\text { Informasi } \\
\text { tidak tersedia }\end{array}$ & Kelompok terbatas \\
\hline 3 & Bandarsyah & & & $\begin{array}{l}\text { Organisasi } \\
\text { (Muhammadiy } \\
\text { ah) }\end{array}$ & Ekslusif & $\begin{array}{l}\text { Informasi } \\
\text { tidak tersedia }\end{array}$ & $\begin{array}{l}\text { Informasi } \\
\text { tidak tersedia }\end{array}$ & Khalayak umum \\
\hline 4 & $\begin{array}{l}\text { Bin Sanusi } \\
\&\end{array}$ & & & Seniman (grup & $\begin{array}{l}\text { Informasi } \\
\text { tidak }\end{array}$ & $\begin{array}{l}\text { Karya seni, } \\
\text { khususnya }\end{array}$ & Informasi & Informasi tidak tersedia \\
\hline
\end{tabular}


"Telaah Literatur Dakwah Di Indonesia"

\begin{tabular}{|c|c|c|c|c|c|c|c|}
\hline & Mohamed & & musik nasyid) & tersedia & $\begin{array}{l}\text { syair dan } \\
\text { musik }\end{array}$ & tidak tersedia & \\
\hline 5 & Bukhari & & $\begin{array}{l}\text { Komunitas } \\
\text { (Jemaah } \\
\text { Tabligh) }\end{array}$ & Ekslusif & $\begin{array}{l}\text { Lisan dan } \\
\text { tindakan }\end{array}$ & $\begin{array}{l}\text { Informasi } \\
\text { tidak tersedia }\end{array}$ & Kelmpok terbatas \\
\hline 6 & Choiriyah & & $\begin{array}{l}\text { Seniman } \\
\text { (penyanyi dan } \\
\text { penulis lagu } \\
\text { profesional) }\end{array}$ & Ekslusif & $\begin{array}{l}\text { Karya seni, } \\
\text { khususnya } \\
\text { syair dan } \\
\text { musik }\end{array}$ & $\begin{array}{l}\text { Informasi } \\
\text { tidak tersedia }\end{array}$ & Khalayak umum \\
\hline 7 & Dalmeri & & $\begin{array}{l}\text { Organisasi } \\
\text { (takmir dan } \\
\text { jemaah masjid) }\end{array}$ & Ekslusif & Lisan & $\begin{array}{l}\text { Informasi } \\
\text { tidak tersedia }\end{array}$ & Khalayak umum \\
\hline 8 & $\begin{array}{l}\text { Dwiningru } \\
\mathrm{m}\end{array}$ & $\begin{array}{l}\text { Institusi } \\
\text { pendidikan } \\
\text { (SMU) }\end{array}$ & & Inklusif & $\begin{array}{l}\text { Lisan dan } \\
\text { tindakan }\end{array}$ & $\begin{array}{l}\text { Informasi } \\
\text { tidak tersedia }\end{array}$ & $\begin{array}{l}\text { Kelompok terbatas (siswa } \\
\text { SMU) }\end{array}$ \\
\hline 9 & $\begin{array}{l}\text { Fatmawati } \\
\text { \& Diania }\end{array}$ & & $\begin{array}{l}\text { Organisasi } \\
\text { (Gafatar) }\end{array}$ & Ekslusif & $\begin{array}{l}\text { Informasi } \\
\text { tidak tersedia }\end{array}$ & $\begin{array}{l}\text { Informasi } \\
\text { tidak tersedia }\end{array}$ & Khalayak umum \\
\hline
\end{tabular}

$438 \mid$ JURNAL LISAN AL-HAL 
“Volume 13, No. 2, Desember 2019"

\begin{tabular}{|c|c|c|c|c|c|c|c|c|}
\hline 10 & Haryanto & & & $\begin{array}{l}\text { Organisasi } \\
\text { (takmir dan } \\
\text { jemaah masjid) }\end{array}$ & Ekslusif & Tulisan & $\begin{array}{l}\text { Informasi } \\
\text { tidak tersedia }\end{array}$ & Informasi tidak tersedia \\
\hline 11 & Hayat & & & $\begin{array}{l}\text { Organisasi } \\
(\mathrm{NU})\end{array}$ & Ekslusif & $\begin{array}{l}\text { Lisan dan } \\
\text { tindakan }\end{array}$ & $\begin{array}{l}\text { Informasi } \\
\text { tidak tersedia }\end{array}$ & Informasi tidak tersedia \\
\hline 12 & Hidayanti & & $\begin{array}{l}\text { Rumah } \\
\text { sakit }\end{array}$ & & Ekslusif & Lisan & $\begin{array}{l}\text { Informasi } \\
\text { tidak tersedia }\end{array}$ & Informasi tidak tersedia \\
\hline 13 & $\begin{array}{l}\text { Hun \& Abu } \\
\text { Hasan }\end{array}$ & & & $\begin{array}{l}\text { Seniman } \\
\text { (novelis) }\end{array}$ & Ekslusif & $\begin{array}{l}\text { Karya seni } \\
\text { (novel) }\end{array}$ & $\begin{array}{l}\text { Informasi } \\
\text { tidak tersedia }\end{array}$ & Khalayak umum \\
\hline 14 & Isnania & & & $\begin{array}{l}\text { Lembaga } \\
\text { Dakwah } \\
\text { Kampus }\end{array}$ & Ekslusif & $\begin{array}{l}\text { Lisan dan } \\
\text { tindakan }\end{array}$ & $\begin{array}{l}\text { Informasi } \\
\text { tidak tersedia }\end{array}$ & Informasi tidak tersedia \\
\hline 15 & Jalil & & & $\begin{array}{l}\text { Majelis } \\
\text { Mujahidin } \\
\text { Indonesia } \\
\text { (MMI) }\end{array}$ & Ekslusif & $\begin{array}{l}\text { Lisan dan } \\
\text { tindakan }\end{array}$ & $\begin{array}{l}\text { Informasi } \\
\text { tidak tersedia }\end{array}$ & Informasi tidak tersedia \\
\hline 16 & $\begin{array}{l}\text { Kholili \& } \\
\text { Hadi }\end{array}$ & Depag RI & & & Ekslusif & $\begin{array}{l}\text { Lisan dan } \\
\text { tindakan }\end{array}$ & $\begin{array}{l}\text { Informasi } \\
\text { tidak tersedia }\end{array}$ & $\begin{array}{l}\text { Kelompok terbatas } \\
\text { (kelompok binaan } \\
\text { Kandepag Kabupaten }\end{array}$ \\
\hline
\end{tabular}


"Telaah Literatur Dakwah Di Indonesia"

\begin{tabular}{|c|l|l|l|l|l|l|l|l|}
\hline & & & & & & Sleman) \\
\hline 17 & $\begin{array}{l}\text { Kusuma \& } \\
\text { Octastefani }\end{array}$ & & $\begin{array}{l}\text { Organisasi } \\
\text { (parpol) }\end{array}$ & Ekslusif & $\begin{array}{l}\text { Lisan dan } \\
\text { tindakan }\end{array}$ & $\begin{array}{l}\text { Informasi } \\
\text { tidak tersedia }\end{array}$ & $\begin{array}{l}\text { Kelompok terbatas } \\
\text { (khalayak umum) }\end{array}$ \\
\hline 18 & Latief & & $\begin{array}{l}\text { Organisasi } \\
\text { (Yayasan) }\end{array}$ & Ekslusif & $\begin{array}{l}\text { Lisan dan } \\
\text { tindakan }\end{array}$ & $\begin{array}{l}\text { Informasi } \\
\text { tidak tersedia }\end{array}$ & Khalayak umum \\
\hline 19 & Ma'arif & & $\begin{array}{l}\text { Individu } \\
\text { (ulama) }\end{array}$ & Inklusif & Lisan & $\begin{array}{l}\text { Informasi } \\
\text { tidak tersedia }\end{array}$ & $\begin{array}{l}\text { Kelompok terbatas } \\
\text { (jemaah pengajian) }\end{array}$ \\
\hline 20 & Ma'arif & & $\begin{array}{l}\text { Individu } \\
\text { (ulama) }\end{array}$ & Ekslusif & $\begin{array}{l}\text { Lisan dan } \\
\text { tindakan }\end{array}$ & $\begin{array}{l}\text { Informasi } \\
\text { tidak tersedia }\end{array}$ & $\begin{array}{l}\text { Kelompok terbatas } \\
\text { (jemaah pengajian) }\end{array}$ \\
\hline 21 & Masmuddin & & $\begin{array}{l}\text { Individu } \\
\text { (ulama) }\end{array}$ & Inklusif & $\begin{array}{l}\text { Lisan dan } \\
\text { tindakan }\end{array}$ & $\begin{array}{l}\text { Informasi } \\
\text { tidak tersedia }\end{array}$ & $\begin{array}{l}\text { Kelompok terbatas (tokoh } \\
\text { lintas agama) }\end{array}$ \\
\hline 22 & Najitama & & $\begin{array}{l}\text { Pondok } \\
\text { pesantren }\end{array}$ & Ekslusif & $\begin{array}{l}\text { Lisan dan } \\
\text { tindakan }\end{array}$ & $\begin{array}{l}\text { Informasi } \\
\text { tidak tersedia }\end{array}$ & $\begin{array}{l}\text { Kelompok terbatas } \\
\text { (jemaah pengajian) }\end{array}$ \\
\hline
\end{tabular}

$440 \mid$ JURNAL LISAN AL-HAL 
“Volume 13, No. 2, Desember 2019"

\begin{tabular}{|c|l|l|l|l|l|l|l|l|}
\hline 23 & Nasrullah & & $\begin{array}{l}\text { Individu } \\
\text { (pengguna } \\
\text { media sosial) }\end{array}$ & Ekslusif & Media sosial & $\begin{array}{l}\text { Teknologi } \\
\text { berbasis } \\
\text { internet }\end{array}$ & $\begin{array}{l}\text { Khayalak umum } \\
\text { (pengguna internet) }\end{array}$ \\
\hline 24 & Novaili & Depag RI & & Ekslusif & Lisan & $\begin{array}{l}\text { Informasi } \\
\text { tidak tersedia }\end{array}$ & Informasi tidak tersedia \\
\hline 25 & Nur'aini & & $\begin{array}{l}\text { Organisasi } \\
\text { ('Aisyiyah) }\end{array}$ & Ekslusif & $\begin{array}{l}\text { Lisan dan } \\
\text { tindakan }\end{array}$ & $\begin{array}{l}\text { Informasi } \\
\text { tidak tersedia }\end{array}$ & Khalayak umum \\
\hline 26 & Pahlevi & $\begin{array}{l}\text { Rachmiatie, } \\
\text { Sidik, } \\
\text { Farihat }\end{array}$ & & $\begin{array}{l}\text { Pondok } \\
\text { pesantren } \\
\text { radio dan } \\
\text { tabloid } \\
\text { komunitas }\end{array}$ & Ekslusif & $\begin{array}{l}\text { Karya seni } \\
\text { (kaligrafi) }\end{array}$ & $\begin{array}{l}\text { informasi } \\
\text { tidak tersedia }\end{array}$ & Kelompok terbatas \\
\hline 28 & Raihan & $\begin{array}{l}\text { Dewan } \\
\text { Dakwah } \\
\text { Islamiyah } \\
\text { Indonesia } \\
\text { Aceh }\end{array}$ & Ekslusif & $\begin{array}{l}\text { Tulisan dan } \\
\text { lisan }\end{array}$ & Radio & Khalayak umum \\
tindakan & $\begin{array}{l}\text { Informasi } \\
\text { tidak tersedia }\end{array}$ & Informasi tidak tersedia \\
\hline
\end{tabular}


"Telaah Literatur Dakwah Di Indonesia"

\begin{tabular}{|c|c|c|c|c|c|c|c|}
\hline 29 & Razzaq & $\begin{array}{l}\text { Perbankan } \\
\text { syariah }\end{array}$ & & Ekslusif & $\begin{array}{l}\text { Lisan dan } \\
\text { tindakan }\end{array}$ & $\begin{array}{l}\text { informasi } \\
\text { tidak tersedia }\end{array}$ & Informasi tidak tersedia \\
\hline 30 & Riyadi & & Rumah sakit & Ekslusif & $\begin{array}{l}\text { Lisan dan } \\
\text { tindakan }\end{array}$ & $\begin{array}{l}\text { informasi } \\
\text { tidak tersedia }\end{array}$ & Informasi tidak tersedia \\
\hline 31 & Rosa & & $\begin{array}{l}\text { Majelis Zikir } \\
\text { SBY } \\
\text { "Nurussalam" }\end{array}$ & Ekslusif & $\begin{array}{l}\text { Lisan dan } \\
\text { tindakan }\end{array}$ & $\begin{array}{l}\text { informasi } \\
\text { tidak tersedia }\end{array}$ & Kelompok terbatas \\
\hline 32 & Saifullah & & $\begin{array}{l}\text { Pondok } \\
\text { pesantren }\end{array}$ & Ekslusif & $\begin{array}{l}\text { Lisan dan } \\
\text { tindakan }\end{array}$ & $\begin{array}{l}\text { Informasi } \\
\text { tidak tersedia }\end{array}$ & Kelompok terbatas \\
\hline 33 & Shobron & & $\begin{array}{l}\text { Organisasi } \\
\text { (Hizbut Tahrir } \\
\text { Indonesia) }\end{array}$ & Ekslusif & $\begin{array}{l}\text { Lisan dan } \\
\text { tindakan }\end{array}$ & $\begin{array}{l}\text { Informasi } \\
\text { tidak tersedia }\end{array}$ & Kelompok terbatas \\
\hline 34 & $\begin{array}{l}\text { Shobron, } \\
\text { Rosyadi, \& } \\
\text { Suaidy }\end{array}$ & & $\begin{array}{l}\text { Pondok } \\
\text { pesantren }\end{array}$ & Ekslusif & $\begin{array}{l}\text { Lisan dan } \\
\text { tindakan }\end{array}$ & $\begin{array}{l}\text { Informasi } \\
\text { tidak tersedia }\end{array}$ & Kelompok terbatas \\
\hline 35 & Shodiq & & $\begin{array}{l}\text { Komunitas } \\
\text { (pengajian }\end{array}$ & Ekslusif & $\begin{array}{l}\text { Lisan dan } \\
\text { tindakan }\end{array}$ & $\begin{array}{l}\text { Informasi } \\
\text { tidak tersedia }\end{array}$ & $\begin{array}{l}\text { Kelompok terbatas } \\
\text { (jemaah pengajian) }\end{array}$ \\
\hline
\end{tabular}

442 JURNAL LISAN AL-HAL 
“Volume 13, No. 2, Desember 2019"

\begin{tabular}{|c|c|c|c|c|c|c|c|c|}
\hline & & & & tarekat) & & & & \\
\hline 36 & Sofjan & & $\begin{array}{l}\text { Stasiun } \\
\text { televisi } \\
\text { swasta }\end{array}$ & & Ekslusif & Multimedia & $\begin{array}{l}\text { Teknologi } \\
\text { penyiaran dan } \\
\text { media sosial }\end{array}$ & Khalayak umum \\
\hline 37 & Sukardi & & & $\begin{array}{l}\text { Individu } \\
\text { (ulama) }\end{array}$ & Ekslusif & Lisan & $\begin{array}{l}\text { Informasi } \\
\text { tidak tersedia }\end{array}$ & Kelompok terbatas \\
\hline 38 & Sunarwoto & & $\begin{array}{l}\text { Korporasi } \\
\text { (MTA FM) }\end{array}$ & & Ekslusif & Lisan & $\begin{array}{l}\text { Informasi } \\
\text { tidak tersedia }\end{array}$ & Khalayak umum \\
\hline 39 & Susanto & & & $\begin{array}{l}\text { Pondok } \\
\text { pesantren }\end{array}$ & Ekslusif & Pengobatan & $\begin{array}{l}\text { Informasi } \\
\text { tidak tersedia }\end{array}$ & Kelompok terbatas \\
\hline 40 & Susanto & & & $\begin{array}{l}\text { Individu (ahli } \\
\text { ruqyah) }\end{array}$ & Ekslusif & Pengobatan & $\begin{array}{l}\text { Informasi } \\
\text { tidak tersedia }\end{array}$ & Kelompok terbatas \\
\hline 41 & Syobah & $\begin{array}{l}\text { TVRI } \\
\text { Kaltim }\end{array}$ & & & Ekslusif & Multimedia & $\begin{array}{l}\text { Teknologi } \\
\text { penyiaran }\end{array}$ & Khalayak umum \\
\hline 42 & Ubaidillah & & & $\begin{array}{l}\text { Individu } \\
\text { (Rasulullah } \\
\text { SAW) }\end{array}$ & Ekslusif & Tulisan & $\begin{array}{l}\text { Informasi } \\
\text { tidak tersedia }\end{array}$ & Kelompok terbatas \\
\hline
\end{tabular}


"Telaah Literatur Dakwah Di Indonesia"

\begin{tabular}{|c|l|l|l|l|l|l|l|l|}
\hline 43 & $\begin{array}{l}\text { Wahyuning } \\
\text { sih }\end{array}$ & & $\begin{array}{l}\text { Seniman } \\
\text { (penulis novel) }\end{array}$ & Ekslusif & $\begin{array}{l}\text { Karya seni } \\
\text { (novel) }\end{array}$ & $\begin{array}{l}\text { Teknologi } \\
\text { penyiaran }\end{array}$ & Khalayak umum \\
\hline 44 & Yusuf & $\begin{array}{l}\text { Komunitas } \\
\text { (Jemaah } \\
\text { tablgih) }\end{array}$ & Ekslusif & $\begin{array}{l}\text { Lisan dan } \\
\text { tindakan }\end{array}$ & $\begin{array}{l}\text { Informasi } \\
\text { tidak tersedia }\end{array}$ & Kelompok terbatas \\
\hline
\end{tabular}

444 JURNAL LISAN AL-HAL 


\section{Simpulan}

Dari analisis deskriptif dan tematik di atas, ada beberapa research gap yang bisa dijadikan agenda penelitian selanjutnya bagi para peneliti yang concern dengan fenomena dakwah. Pertama, secara metodologi, penggunaan pendekatan kuantitatif perlu terus ditingkatkan, terutama statistik inferensial, karena lebih memberikan kepastian soal kausalitas. Kedua, sumber dan jenis data yang lebih variatif (misalnya, panel data, big data, social network data) perlu diadopsi untuk mendapatkan pemahaman yang lebih baik. Ketiga, fenomena dakwah perlu dipahami dengan menggunakan beragam sudut pandang teoritis dari beragam disiplin ilmu. Keempat, beberapa isu yang sudah diidentifikasi penelitian sebelumnya perlu dijadikan titik tolak untuk mengembangkan road map penelitian dakwah di Indonesia. Kelima, populasi dan sampel da'i dan mad'u perlu diperluas dengan melibatkan aktor-aktor yang berdakwah di dunia online. Keenam, khusus untuk disiplin ilmu komunikasi, kami menyarankan agar fokus untuk mengelaborasi lebih jauh konsep pesan yang 'membekas pada jiwa' (Q.S An-Nisä [4]: 63). Ketujuh, banyaknya informasi dakwah yang beredar di internet membuat aspek literasi digital para mad'u semakin relevan untuk ditelaah secara ilmiah. Hal ini sejalan dengan perintah Allah SWT yang meminta agar orang beriman bersikap kritis terhadap lalu lintas dan validitas informasi (Q.S Al-Hujurat [49]: 6).

Hasil analisis deskriptif dan tematik telaah pustaka ini mengandung beberapa implikasi praktis bagi dunia publikasi riset di Indonesia. Pertama, di tingkat penulis, narasi metode penelitian (sumber data, teknik pengumpulan, teknik analisis data, dan validasi data), limitasi penelitian, dan agenda penelitian selanjutnya dalam manuskrip perlu diberi perhatian khusus. Kedua, bagi para aktor yang terlibat dalam pengelolaan jurnal, baik editor maupun reviewer, khususnya yang terindeks di Directory Open Access Journal (DOAJ), perlu dipikirkan upaya membuat standarisasi sistematika dan penilaian artikel dalam proses review. Ketiga, bagi pihak DOAJ, kami menyarankan agar ada penambahan fasilitas citation export di website DOAJ yang tidak hanya berisi bibliography information, citation information, abstact dan keyword, tetapi juga data referensi setiap artikel sehingga DOAJ bisa dijadikan sumber data penelitian citation networking. Keempat, bagi perguruan tinggi, perlu dipikirkan untuk membuat proyek penelitian bersama lintas perguruan tinggi yang akan menghasilkan data panel tentang perilaku da'i, mad'u, dan relasi da'i - mad'u dalam tempat dan kurun waktu yang berbeda.

Penelitian ini memiliki dua kelemahan. Pertama, kami hanya 
membatasi artikel yang terbit di jurnal yang dikelola oleh penerbit Indonesia dan terindeks di DOAJ. Padahal, ada 36 artikel yang mengandung kata dakwah di SCOPUS. Kami sengaja mengeluarkan SCOPUS karena ingin melihat konstruksi pengetahuan yang ditulis para sarjana Indonesia. Konsekuensinya, hasil telaah pustaka mungkin sangat bias dan belum mencerminkan peta riset dakwah yang dihasilkan para peneliti di Indonesia. Kedua, proses pencaharian dokumen dengan kata 'dakwah' di judul, abstrak, dan keyword juga berimbas terhadap penemuan dokumen. Jika proses penelusuran dokumen dilakukan tanpa penyaringan mungkin akan menemukan lebih banyak artikel yang berpotensi di analisis.

\section{DAFTAR PUSTAKA}

Abdurrazaq, Abdurrazaq."Analisis Pesan Dakwah Dalam Karya Sastra: Studi Atas Publikasi Novel-Novel Islami Karya Habiburrahman El-Shirazy." Intizar: Jurnal Kajian dan Kemasyarakatan 19(2): 2013.

Ahmadi, Dadi, and Nova Yohana. "Konstruksi Jilbab Sebagai Simbol Keislaman." MediaTor: Jurnal Komunikasi 8(2): 2007.

Armstrong, Karen. "Resisting Modernity: The Backlash Againts Secularism." Harvard International Review 25(4): 2004.

Arsam, Arsam. "Dialog Interaktif Sebagai Upaya Evaluasi Dakwah." ADDIN 8(2): 2014.

Bandarsyah, Desvian. "Dinamika Tajdid Dalam Dakwah Muhammadiyah." Jurnal HISTORIA 4(2): 2016.

Van Bruinessen, Martin. "Genealogioes of Islamic Radicalism in PostSoeharto Indonesia." South East Asia Research 10(2): 2002.

Bukhari, Bukhari. "Penerimaan Dan Penolakan Pesan Dakwah Dalam Interaksi Simbolik Da'i Dan Mad'u Pada Jamaah Tabligh Di Kota Padang." MIQOT: Jurnal Ilmu-Ilmu Keislaman 29(2): 2015.

Burhani, Ahmad Najib. "Fundamentalism and Religious Dissent: The LPPI's Mission to Eradicate the Ahmadiyya in Indonesia." Indonesia and the Malay World 44(129): 2016. http://dx.doi.org/10.1080/13639811.2015.1135610\%5Cnhttp://www.tan dfonline.com/doi/full/10.1080/13639811.2015.1135610.

Choiriyah. "Izinkan Aku Reguk Cintamu Dalam Lirik Lagu Ebiet G. Ade: Analisis Materi Dakwah." Intizar: Jurnal Kajian dan Kemasyarakatan 19(2): 2013.

Dalmeri. "Revitalisasi Fungsi Masjid Sebagai Pusat Ekonomi Dan Dakwah." 446 JURNAL LISAN AL-HAL 
Walisongo: Jurnal Penelitian Sosial dan Keagamaan 22(November): 2014.

Diania, Vicky, and Fatmawati Fatmawati. "Paradigma Dakwah Gafatar Di Dunia Maya Dalam Perspektif Shifting Paradigm." Jurnal Madania 20(2): 2016.

Dwiningrum, Siti Irene Astuti. "Multicultural Da'wa in Schools from a Sociological Perspective." Walisongo: Jurnal Penelitian Sosial dan Keagamaan 22(2): 2014.

Ecarnot, F et al. "Writing a Scientific Article: A Step-by-Step Guide for Beginners." European Geriatric Medecine 6(6): 573-79. http://dx.doi.org/10.1016/j.eurger.2015.08.005. 2015.

Elder-Vass, Dave. The Causal Power of Social Structures: Emergence, Structure and Agency. Cambridge, UK: Cambridge University Press. 2010.

Faye, Jan. "Explanation and Interpretation in the Sciences of Man." In Explanation, Prediction, and Confirmation, eds. Dennis Dieks et al. New York, USA: Springer Science + Business Media B.V, 2011.

Haryanto, Haryanto. "Pesan Dakwah Pada Buletin Jum'at Himmah IAIN Palangka Raya." Jurnal Studi Agama dan Masyarakat 12(1): 2016.

Hayat, Hayat. "Pengajian Yasinan Sebagai Strategi Dakwah NU Dalam Membangun Mental Dan Karakter Masyarakat." Walisongo: Jurnal Penelitian Sosial dan Keagamaan 22(2): 2014. http://journal.walisongo.ac.id/index.php/wali/article/view/192.

Hidayanti, Ema. "Dakwah Pada Setting Rumah Sakit: (Studi Deskriptif Terhadap Sistem Pelayanan Bimbingan Konseling Islam Bagi Pasien Rawat Inap Di RSI Sultan Agung Semarang).” KONSELING RELIGI: Jurnal Bimbingan Konseling Islam 5(2): 2014.

Hun, Koh Young, and Ummi Hani Abu Hassan. "DAKWAH, WEALTH AND DESIRE OF SEXUALITY IN ISLAM: THE CONCEPT OF LOVE IN HABIBURRAHMAN EL-SHIRAZY'S AYAT-AYAT CINTA 2." Indonesian Language Education and Literature 2(2): 2017. https://www.syekhnurjati.ac.id/jurnal/index.php/jeill/article/view/1458.

Ioannidis, John P A. "Limitations Are Not Properly Acknowledged in the Scientific Literature." Journal of Clininal Epidemiology 60: 2007.

Isnaniah, Siti. "Kajian Sosiolinguistik Terhadap Bahasa Dakwah Aktivis Dakwah Kampus (ADK) Surakarta." KARSA 21(2): 2013.

Jalil, Abdul. "Dakwah MMI (Mengurai Kekerasan Sosial Pada Diskusi Di LKiS Yogyakarta)." al-Balagh: Jurnal Dakwah dan Komunikasi 1(1): 2016. 
Jinan, Muhammad. "Intervensi New Media Dan Impersonalisasi Otoritas Keagamaan Di Indonesia.” Jurnal Komunikasi Islam 3(2): 2013.

Kholili, H M, and Syamsul Hadi. "Islam Yang Rahmat Dalam Membangun Umat: Studi Terhadap Dakwah Paif Kabupaten Sleman.” Kawistara: The Journal of Social Science and Humanities 4(3): 2014.

Kuhn, Thomas S. The Structure of Scientific Revolutions. Third Edit. London, UK: The University of Chicago Press. 1996.

Kusuma, Bayu Mitra A, and Theresia Octastefani. "Negosiasi Dakwah Dan Politik Praktis: Membaca Orientasi Organisasi Sayap Keagamaan Islam Pada Partai Nasionalis.” al-Balagh: Jurnal Dakwah dan Komunikasi 2(1): 2017.

Latief, Hilman. "Islamic Charities and Dakwah Movements in A Muslim Minority Island: The Experience of Niasan Muslims." Journal of Indonesian Islam 6(2): 2012.

Ma'arif, Bambang Saiful. "Pola Komunikasi Dakwah KH. Abdullah Gymnastiar Dan KH. Jalaluddin Rakhmat.” Mimbar: Jurnal Sosial dan Pembangunan XXV(2): 2009. http://mimbar.lppm.unisba.ac.id/index.php/mimbar/article/view/121. "Dimensi Inklusi Dakwah KH. Abdullah Gymnastiar Dan KH. Jalaludin Rakhmat.” Mimbar: Jurnal Sosial dan Pembangunan 27(1): 2011.

Masmuddin, Masmuddin. "Komunikasi Antar Umat Beragama Di Kota Palopo (Perspektif Kajian Dakwah).” Jurnal Studi Agama dan Masyarakat 13(1): 2017.

Von Der Mehden, Fred R. "Religion and Development in South-East Asia: A Comparative Study." World Development 8(7-8): 1980.

Muchtar, N., and J. A. Ritchey. "Preaching, Community, and Convergence: Use of Old and New Media by Progressive Indonesian Islamic Leaders." International Communication Gazette 76(4-5): $2014 .$. http://gaz.sagepub.com/content/76/4-5/360.abstract.html?etoc.

Muzakki, Akh. "Current Debates in the Post-Soeharto Indonesian Islam: Examining the Intelletual Base of Liberal and Anti-Liberal Islamic Movement." Al-Jami'ah: Journal of Islamic Studies 45(2): 2007..

Najitama, Fikria. "Blangkon Hitam: Identitas Gerakan Padepokan Dakwah Sunan Kalijaga Dalam Masyarakat." el Harakah 18(1): 2016.

Nasrullah, Rulli. “Aplifikasi Islam Dalam Meme.” el Harakah 18(2): 2016.

Novaili, Novaili. "Metode Dakwah Penyuluh Agama Islam Dalam Mewujudkan Keluarga Sakinah Terhadap Pasangan Calon Suami Isteri $448 \mid$ JURNAL LISAN AL-HAL 
Di Kantor Urusan Agama (KUA)." KONSELING RELIGI: Jurnal Bimbingan Konseling Islam 6(2): 2015.

Nura'ini, Dyah Siti. "Corak Pemikiran Dan Gerakan Aktivis Perempuan (Melacak Pandangan Keagamaan Aisyiyah Periode 1917-1945)." PROFETIKA: Jurnal Studi Islam 14(2): 2013.

Pahlevi, Reza. "Dakwah Kultural Bayt Al-Qur'an Al-Akbar Ukiran Kayu Khas Melayu Palembang." Intizar: Jurnal Kajian dan Kemasyarakatan 22(1): 2016.

Popper, Earl R. 12 Physics Today The Logic of Scientific Discovery. New York, USA: Taylor \& Francis eLibrary. 2005.

Psillos, Stathis. "Past and Contemporary Perspectives on Explanation." In Handbook of the Philosophy of Science: General Philosophy of Science: Focal Issues, ed. Theo A. F. Knipers. Amsterdam, Netherland: Elsevier B.V. 2007.

Rachmiatie, Atie, Asep Ahmad Sidik, and Farihat Farihat. "Proses Sosialisasi Informasi Agama Islam Melalui Media Komunitas Sebagai Pembentuk Moralitas Remaja Muslim." Mimbar: Jurnal Sosial dan Pembangunan 23(1): 2004.

Rahim, Lily Zubaidah. "Discursive Contest between Liberal and Literal Islam in Southeast Asia." Policy and Society 25(4): 2006. http://search.proquest.com/docview/59785869?accountid=13042\%5Cn http://oxfordsfx.hosted.exlibrisgroup.com/oxford?url_ver=Z39.882004\&rft_val_fmt=info:ofi/fmt:kev:mtx:journal\&genre=article\&sid=Pr oQ:ProQ\%3Awpsa\&atitle=Discursive+Contest+between+Liberal+and $+\mathrm{L}$.

Raihan, Raihan. "Implementasi Pemikiran Dakwah Mohammad Natsir Di Dewan Dakwah Islamiyah Indonesia Provinsi Aceh." Jurnal Ilmiah Islam Futura 15(1): $67 . \quad$ http://jurnal.arraniry.ac.id/index.php/islamfutura/article/view/559. 2015.

Ratri, Lintang. "Cadar, Media, Dan Identitas Perempuan Muslim." Forum 39(2): 2011.

Razzaq, Abdur. "Pengembangan Model Pembangunan Ummat Melalui Lembaga Filantropi Islam Sebagai Bentuk Dakwah Bil Hal.” Intizar: Jurnal Kajian dan Kemasyarakatan 20(1): 2014.

Riyadi, Agus. "Dakwah Terhadap Pasien: Telaah Terhadap Model Dakwah Melalui Sistem Layanan Bimbingan Rohani Islam Di Rumah Sakit." KONSELING RELIGI: Jurnal Bimbingan Konseling Islam 5(2): 2014.

Rosa, Andi. "Politik Dakwah Dan Dakwah Politik Di Era Reformasi Indonesia." Walisongo: Jurnal Penelitian Sosial dan Keagamaan 
22(1): 2014.

Saifulah. "Dakwah Multikultural Pesantren Ngalah Dalam Meredam Radikalisme Agama." Islamica: Jurnal Studi Keislaman 8(2): 2014.

Bin Sanusi, Eri Satria, and Roslan Mohamed. "Analisis Terhadap Peranan Nasyid Dalam Dakwah.” Jurnal Ilmiah Islam Futura 16(2): 2017.

Schiffer, Michael Brian. The Archaeology of Science: Studying the Creation of Useful Knowledge. Basel, Switzerland: Springer International Publishing Switzerland. 2013.

Shobron, Sudarno. "Model Dakwah Hizbut Tahrir Indonesia." PROFETIKA: Jurnal Studi Islam 15(1): 2014.

Shobron, Sudarno, Imron Rosyadi, and Mohammad Zaki Suaidy. "Dakwah Bil-Hal Pesantren Walisongo Ngabar Ponorogo Jawa Timur Dalam Pemberdayaan Ekonomi Masyarakat Tahun 2013-2014." PROFETIKA: Jurnal Studi Islam 16(1): 2015.

Shodiq, Muhammad. "Eksistensi Dan Gerakan Dakwah Tarekat Siddiqiyah Di Tengah Masyarakat Urban Surabaya." Teosofi: Jurnal Tasawuf dan Pemikiran Islam 5(2): 2015.

Shughart II, William F. "An Analytical History of Terrorism, 1945-2000." Public Choice 128(1/2): 2006.

Sofjan, Dede. "Gender Construction in Dakwahtainment: A Case Study of Hati Ke Hati Bersama Mamah Dedeh." Al-Jami'ah: Journal of Islamic Studies 50(1): 2012.

Sukardi, Sukardi. "Dakwah Bi Al-Lisan Dengan Teknik Hiburan Di Kota Banda Aceh." Jurnal Ilmiah Islam Futura 14(1): 2014.

Sunarwoto, Sunarwoto. "Radio Fatwa: Islamic Tanya-Jawab Programmes on Radio Dakwah.” Al-Jami'ah: Journal of Islamic Studies 50(2): 2012.

Susanto, Dedy. "Psikoterapi Religius Sebagai Strategi Dakwah Dalam Menanggulangi Tindak Sosiopatic." KONSELING RELIGI: Jurnal Bimbingan Konseling Islam 4(1): 2013.

."Dakwah Melalui Layanan Psikoterapi Ruqyah Bagi Pasien Penderita Kesurupan." KONSELING RELIGI: Jurnal Bimbingan Konseling Islam 4(2): 2014.

Syobah, Sy Nurul. "Bentuk Dan Efektivitas Dakwah Di TVRI Kalimantan Timur." FENOMENA 7(32): 2015.

Ubaidillah, Ubaidillah. "Surat Dakwah Nabi Muhammad SAW (Analisis Tematik Atas Surat-Surat Nabi Muhammad Kepada Para Raja)." IBDA': Jurnal Kebudayaan Islam 13(1): 2015.

Wahyuningsih, Sri. "Representasi Pesan-Pesan Dakwah Dalam Film Ayat-

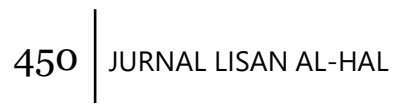


Ayat Cinta.” KARSA 21(2): 2013.

Wasserman, Stanley, and Katherine Faust. Social Network Analysis: Methods and Application. Cambridge, UK: Cambridge University Press. 1994.

Yapp, M. E. "Review Article: Islam and Islamism." Middle Eastern Studies 40(2): 2004.

Yusuf, Moh. "Prinsip Ikram Al-Muslim Gerakan Dakwah Jamaah Tabligh Dalam Membangun Masyarakat Religius Di Temboro Magetan." Islamica: Jurnal Studi Keislaman 10(2): 2016. 